\title{
Pseudoteloceras, a new stephanoceratid genus (Ammonitida) of the lower Humphriesianum Zone (lower Bajocian, Middle Jurassic) from western Tethys
}

\author{
Giulio Pavia ${ }^{a, *}$, Sixto Fernandez-Lopez ${ }^{\mathrm{b}}$ \\ a Dipartimento di Scienze della Terra, via Valperga Caluso 35, 10125 Torino, Italy \\ bepartamento de Paleontología, Facultad de Ciencias Geológicas, calle José Antonio Novais, 2, Universidad Complutense de Madrid, 28040 Madrid, Spain
}

\section{A R T I C L E I N F O}

\section{Article history:}

Received 23 September 2015

Received in revised form 15 December 2015

Accepted 17 December 2015

Available online 7 March 2016

\section{Keywords:}

Ammonites

Stephanoceratidae

Humphriesianum Zone

Romani Subzone

Mediterranean-Caucasian Subrealm

Western Tethys

\begin{abstract}
A B S T R A C T
The new dimorphic genus Pseudoteloceras (type-species: P. crosillense gen. et sp. nov.) is defined within the subfamily Stephanoceratinae. It constitutes the terminal step of an early Bajocian phyletic trend that produces Teloceras-like morphologies throughout the lower Humphriesianum Zone of the western Mediterranean-Caucasian Subrealm, at an older chronological interval and with morpho-structural features that stand apart from those of the best known genus Teloceras of the uppermost Humphriesianum and lower Niortense zones at the early/late Bajocian transition. Three new species are described: $P$. croisillense, $P$. maerteni and $P$. boursicoti. Their biochronostratigraphical ranges are confirmed by the distribution in expanded sections of the Subalpine Basin in Submediterranean Province (Digne area) and the taphonomic analysis of fossil assemblages from the condensed sections of the "Oolithe ferrugineuse de Bayeux" Formation in Calvados, North West European Province. The biochronostratigraphical range of Pseudoteloceras gen. nov. is limited to the Romani Subzone, lower Humphriesianum Zone. P. crosillense gen. et sp. nov. marks a well-defined biohorizon of the upper Romani Subzone in the Digne stratigraphical successions. The extreme degree of the cadiconic morphology in the inner whorls of $P$. boursicoti gen. et sp. nov., and the biostratigraphical gap separating the first appearance of the genus Teloceras in the upper Humphriesianum Zone, support its erection as a new taxon Pseudoteloceras gen. nov. A fourth species, Pseudoteloceras geometricum (Maubeuge), is interpreted as the earliest species of this phyletic lineage, derived from Stemmatoceras and widely distributed through western Tethys in the lower Humphriesianum Zone.
\end{abstract}

(c) 2016 The Geologists' Association. Published by Elsevier Ltd. All rights reserved.

\section{Introduction}

The pandemic family Stephanoceratidae Neumayr, 1875, one of the five families of the Middle to Late Jurassic superfamily Stephanoceratoidea Neumayr, 1875, evolves from the Otoitidae Mascke, 1907, at the Aalenian/Bajocian transition (FernandezLopez, 2014; Fernandez-Lopez and Pavia, 2015) and ranges throughout the Bajocian and Bathonian. It consists of three classical subfamilies Stephanoceratinae Neumayr, 1875, Garantianinae Wetzel, 1937, and Cadomitinae Westermann, 1956, and in addition two new early Bajocian subfamilies were recently defined: Mollistephaninae Fernandez-Lopez and Pavia, 2015, and Frebolditinae Fernandez-Lopez and Pavia, 2015 (for diagnostic

\footnotetext{
* Corresponding author. Tel.: +39 0116705195; fax: +39 0116705339.

E-mail addresses: giulio.pavia@unito.it (G. Pavia), sixto@ucm.es (S. Fernandez-Lopez).
}

features see Fernandez-Lopez and Pavia, 2015, p. 2, and references therein).

The subfamily Stephanoceratinae is characterized by serpenticonic, planorbiconic, platyconic and cadiconic shells and primary ribs with tubercles at the furcation points on the outer flank, and secondary ribs uninterrupted on the venter. Two dimorphs are differentiated: (1) microconchs [m] with lateral lappets and short body-chambers that are ribbed to the termination, and (2) macroconchs $[\mathrm{M}]$ with a simple aperture and relatively long body-chamber (in excess of $360^{\circ}$ ) that is smooth or distantly ribbed. The septal suture is usually complex with 1 st lateral saddle $\mathrm{E} / \mathrm{L}$ asymmetric and higher than the second lateral saddle $\mathrm{L} / \mathrm{U}$, dominant 1st lateral lobe, supplementary lobe $\left(\mathrm{U}_{2}\right)$ on $\mathrm{L} / \mathrm{U}$, and well-developed, retracted umbilical lobe (U) (Arkell et al., 1957; Callomon, 1981, 1985; Page, 1993, 1996, 2008; Moyne and Neige, 2004; Howarth, 2013; Fernandez-Lopez, 2014).

On the basis of these morpho-structural features, Stephanoceratinae display diverse evolutionary trends interpreted as a 
monophyletic group. This subfamily clade brings together a morphologically complex group of lineages and supraspecific taxa throughout early to early-late Bajocian, such as:

- Albarracinites Fernandez-Lopez, 1985, planorbicones distributed in the Discites and Laeviuscula zones (type species A. albarraciniensis Fernandez-Lopez, 1985, p. 301, pl. 36, fig. 1, holotype from the Laeviuscula Zone, Albarracin, Spain).

- Skirroceras Mascke, 1907 (and synonyms proposed by Arkell et al., 1957), planorbicones or platycones to serpenticones distributed from the Laeviuscula to the lowermost Humphriesianum zones (type-species Ammonites Humphriesianum macer Quenstedt 1886, in 1883-1888, p. 528, pl. 65, fig. 11, lectotype designed by Buckman, 1921 in 1909-1930, pl. 248, from the "Humphriesianum-Oolith", Swabia, Germany).

- Stephanoceras Waagen, 1869 (and synonyms proposed by Arkell et al., 1957), platycones to planorbicones distributed from the upper Laeviuscula to the lowermost Niortense zones (type species Ammonites Humphriesianus J. de C. Sowerby, 1825 in Sowerby and Sowerby, 1812-1846, pl. 500, holotype from the lower Bajocian, Oborne, Dorset, England).

- Teloceras Mascke, 1907, cadicones distributed from the uppermost Humphriesianum to the lower Niortense zones (type species Ammonites blagdeni J. Sowerby, 1818 in Sowerby and Sowerby, 1812-1846, p. 231, pl. 201, holotype from the uppermost Humphriesianum Zone, Oborne, Dorset).

With respect to this group of selected taxa, it is worth mentioning that the transition from Stephanoceras to Teloceras is represented by the subcadiconic to planorbiconic forms historically referred to as a branch of the genus Stemmatoceras, Mascke, 1907, but recently assembled into the subgenus Teloceras (Paviceras) Gauthier, Rioult and Trévisan, 1996, from the upper part of the Humphriesianum Zone (type-species Stemmatoceras hoffmanni Schmidtill and Krumbeck, 1938, p. 348, pl. 13, fig. 6, lectotype designed by Pavia, 1983, p. 115, pl. 21, fig. 4, from the “Obere Humphriesi-Schichten”, North Bavaria, Germany).

Besides Teloceras (Paviceras), a second lineage involving subcadiconic to planorbiconic stephanoceratins evolves into the subfamily Cadomitinae whose dimorphic partner is [M] Cadomites Munier-Chalmas, 1892 (type-species Ammonites Deslongchampsi Defrance in d'Orbigny, 1846 in 1842-1851, p. 405, pl. 138, figs. 1-2, holotype by original designation from the upper Bajocian of Calvados, France) and [m] Polyplectites Mascke, 1907 (type-species Ammonites linguiferus d'Orbigny, 1846 in 1842-1851, p. 402, pl. 136, figs. 4-5, neotype designed by Westermann, 1954, p. 338, on de Grossouvre, 1930, pl. 40, fig. 10, from the upper Bajocian of Calvados, France) span from the uppermost lower Bajocian Humphriesianum Zone to the upper Bathonian/lower Callovian transition (Sandoval, 1983; Fernandez-Lopez, 1985; Dietl and Herold, 1986; Fernandez-Lopez and Pavia, 2015). The genus Lokuticeras Galácz, 1994 (type-species Lokuticeras rossbrunnense Galácz, 1994, p. 165, pl. 1, fig. 1, holotype from the uppermost Humphriesianum Zone, Lókút, Bakony Mountains, Hungary) and its microconch counterpart Masckeites Buckman, 1920 in 19091930 (type-species Masckeites densus Buckman, 1920 in 19091930, pl. 152, holotype from the Humphriesianum Zone of Sherborne, Dorset) may be regarded as the ancestor of Cadomitinae in the uppermost Humphriesianum Zone (Galácz, 1994; Pavia and Zunino, 2012).

A third group of Stephanoceratinae includes two mid-lower Bajocian subcadiconic to planorbiconic genera whose phyletic position is still debated in relation to the taxa discussed above: (1) Kumatostephanus Buckman, 1922 (type-species Kumatostephanus kumaterus Buckman, 1922 in 1909-1930, pls. 345 a-b, holotype from the Propinquans Zone of Sherborne, Dorset) and (2)
Stemmatoceras Mascke, 1907 (type species Ammonites Humphriesianum coronatus Quenstedt, 1886 in 1883-1888, p. 539, pl. 66, fig. 11 = Stemmatoceras frechi Renz, 1904, holotype from the Humphriesianum-Oolith of Eningen, Swabia, Germany, refigured by Weisert, 1932, p. 23, pl. 18, fig. 4, as Stemmatoceras coronatum, Schlegelmilch, 1985, p. 77, pl. 27, fig. 6, and Ohmert, 1990, pl. 1, fig. 1 ), referred to as the passage between the Propinquans and the Humphriesianum zones, whose strong, club-like ribbing and less deeply incised suture lines do not support any clear connection to the most typical stephanoceratins, as indicated by many authors (e.g., Ohmert, 1994; Ohmert et al., 1995; Chandler et al., 2013; Dietze et al., 2015).

A further stock of subcadiconic to planorbiconic Stephanoceratinae consists of Teloceras-like forms in the inner whorls, with strong ribbing, large and depressed whorl-section, and crater-like umbilicus. Frequently referred to as Stemmatoceras, they are limited to the uppermost Propinquans and the basal Humphriesianum zones (Maubeuge, 1951; Mouterde, 1953; Morton, 1971; Parsons, 1976; Pavia, 1983; Fernandez-Lopez, 1985; Callomon and Chandler, 1990; Ohmert, 1988, 1990, 1994; Ohmert et al., 1995; Gauthier et al., 1996; Pavia and Martire, 2010; Pavia et al., 2013; Chandler \& Whicher, 2015). Most of these records may be referred to the "Ammonites Blagdeni non Sowerby, 1818" described by d'Orbigny (1847 in 1842-1851) from the lower Bajocian of LesMoutiers-en-Cinglais in Calvados. We focus our attention here on these particular Teloceras-like ammonites with supplementary field researches on the lower Bajocian of the Digne successions (Pavia, 1983) and of the area south of Caen (Pavia et al., 2013, 2015) where the presently unnamed species are fairly common and constitute a homogeneous morphological trend that is different from that of Teloceras s.s.

This study aims to (1) define the systematic status of these Teloceras-like stephanoceratins by erecting a new genus with new or renamed specific taxa, (2) characterize these taxa by morphostructural criteria by comparison with other Stephanoceratinae of the passage between the Propinquans and the Humphriesianum zones, (3) delineate possible phyletic relationships and palaeobiogeographical constraints.

\section{Material and methods}

This study is based on the ammonites collected from two different stratigraphical contexts pertaining to the Mediterranean and the north-western European Jurassic areas of the Mediterranean-Caucasian Subrealm (Fernandez-Lopez and Pavia, 2015):

(1) The thick Bajocian successions of the Digne area (Subalpine Basin, SE France) where the sections of the "Marno-calcaires à Cancellophycus" Formation (Graciansky et al., 1982) are expanded and the fossils are preserved following resedimentation processes. Specimens come from the sections of the Ravin du Feston and the Ravin de la Coueste at Chaudon (Digne area, Alpes de Haute Provence: Pavia, 1983; Pavia and Zunino, 2012) (Fig. 1).

(2) The thin Bajocian successions of the sector south of Caen (Calvados, NW France) where the condensed sections of the "Oolithe ferrugineuse de Bayeux" Formation (Rioult et al., 1991, and references therein) are reduced by recurrent discontinuities and the fossils are commonly preserved as reelaborated elements (i.e. exhumed and displaced before their final burial: Fernandez-Lopez, 1991, 1995, 2007, 2011; Fernandez-Lopez \& Pavia, 2015). The specimens come from outcrops of Feuguerolles-sur-Orne, Bretteville-sur-Odon, Evrecy, Maizet and Les Fours à Chaux at Croisilles (Fig. 2) (Gauthier et al., 1996; Pavia and Martire, 2010; Pavia et al., 2013, 2015). 


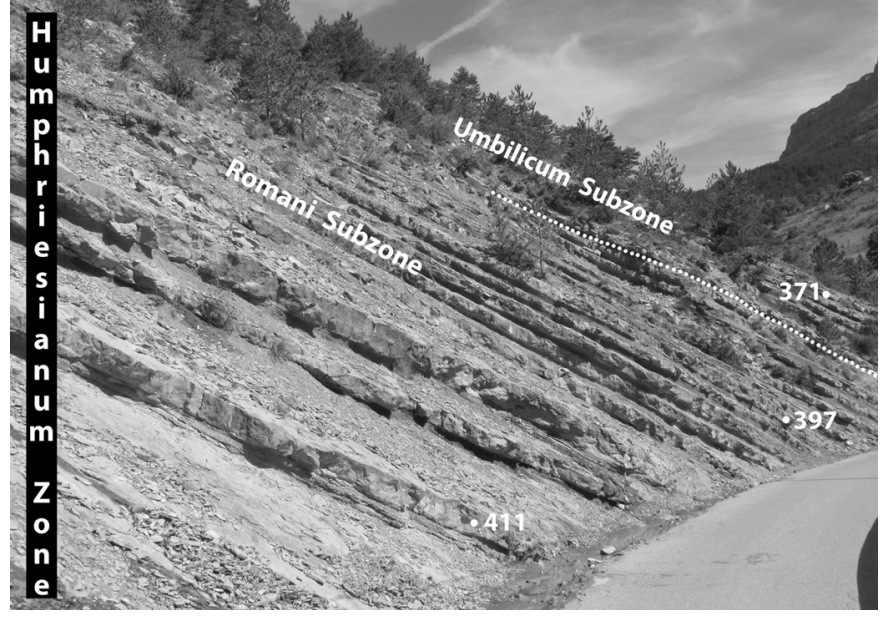

Fig. 1. The lower part of the Humphriesianum Zone in the section of Chaudon, cropping out just beside the Napoleonic Road from Norante-Chaudon to Digne, Subalpine Basin. Numbers of beds are the same as used by Pavia (1983): odd numbers refer to marly limestone beds, even numbers to marly interbeds.

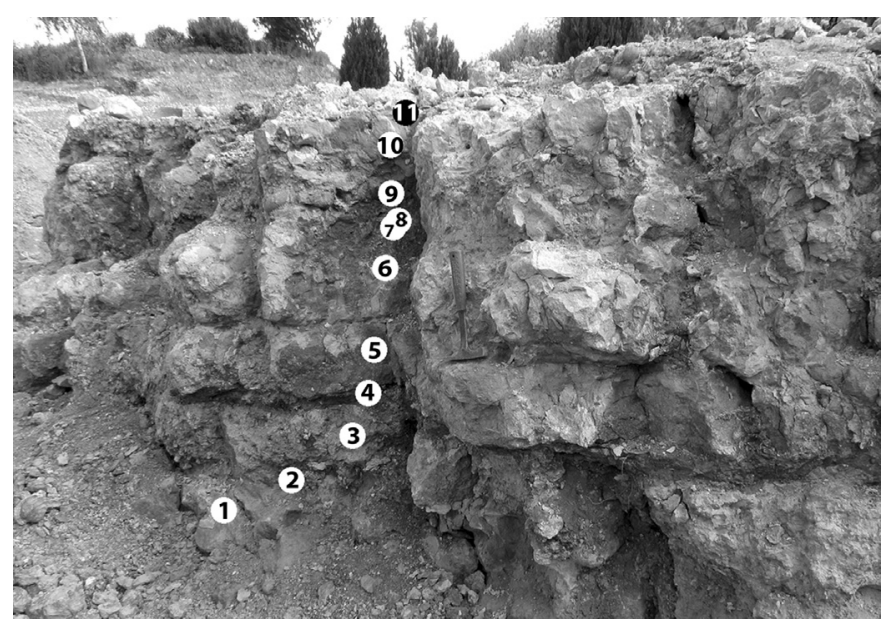

Fig. 2. The section of Les Fours à Chaux at Croisilles. Numbers of beds are the same as used by Pavia et al. (2015). Beds 1-9 refer to the lower Bajocian (Laeviuscula to Humphriesianum zones), beds 10-11 to lowermost upper Bajocian (Niortense Zone). Bed 6 is the source of the Pseudoteloceras gen. nov. specimens discussed herein.

Ammonites from the Bajocian of Digne are essential for biochronostratigraphical purposes as they allow defining the stratigraphical succession of taxa in chronological order, whereas the well preserved fossils of Calvados aid in the description of structural and morphological features. The integration of data from two such different geological settings is possible as the cited authors demonstrated that a detailed taphonomic analysis could provide biochronological information even from fossils obtained from condensed sections (see also Fernandez-Lopez and Pavia, 2015). In particular, Pavia et al. (2013, 2015), respectively for the sections of Maizet and Croisilles in Calvados, distinguished between resedimented specimens (i.e. taphonomic elements displaced after accumulation on the sea floor and prior to the burial; therefore, coeval to the encasing sediment) and reelaborated ones (i.e. taphonomic elements exhumed and displaced before the final burial in expanded deposits; therefore, older than the sedimentary matrix). Such analyses, based on diverse mechanisms of taphonomic alteration (Fernandez-Lopez, 1991, 1995, 2007, 2011), allow the temporal order of the preserved specimens to be ascertained within the biochronological succession and the diverse depositional patterns represented by the stratigraphical intervals of the study.

The biostratigraphical and biochronostratigraphical classifications and units proposed by Rioult et al. (1997) are referred to herein as they are accepted almost unanimously (see Sandoval et al., 2001, 2002; Callomon, 2003; Fernandez-Lopez and Pavia, 2015, and references therein). The ammonite Standard Zonation, dividing the Bajocian Stage of the Mediterranean-Caucasian Subrealm, is as follows from bottom up: lower Bajocian: Discites Zone, Laeviuscula Zone, Propinquans Zone (Patella, Hebridica subzones), Humphriesianum Zone (Romani, Umbilicum, Blagdeni subzones); upper Bajocian: Niortense Zone, Garantiana Zone, Parkinsoni Zone.

The morphological terminology used in the following descriptions follow the Glossary of the Treatise on Invertebrate Paleontology (Arkell et al., 1957) and other terms presented by Westermann (1996, 2005) and by Fernandez-Lopez (2014). Ammonite abbreviations and measurements (in $\mathrm{mm}$ ) are as follows: $\mathrm{M}$, macroconch; $\mathrm{m}$, microconch; D, maximum shell diameter; $\mathrm{H}$, whorl height; h, \% of whorl height to diameter; $\mathrm{W}$, whorl width; $w$, \% of whorl width to diameter; $U$, umbilical diameter; $\mathrm{u}$, \% of umbilicus to diameter; $\mathrm{W} / \mathrm{H}$, ratio of whorl width to whorl height; $\mathrm{Ni} / 2$, internal ribs per half whorl; $\mathrm{Ne} / 2$, external ribs per half whorl; $\mathrm{Ne} /$ $\mathrm{Ni}$, ratio of external to internal ribs.

All the studied specimens are stored in the paleontological collections of the Museo di Geologia e Paleontologia of the Torino University, with code MGPT-PU and have successive catalogue numbers, except for one ammonite provisionally housed in the Lionel Maerten collection (code LM, Ver-sur-Mer, France).

\section{Systematic palaeontology}

Class Cephalopoda Cuvier, 1795

Subclass Ammonoidea von Zittel, 1884

Order Ammonitida Fischer, 1882

Superfamily Stephanoceratoidea Neumayr, 1875

Family Stephanoceratidae Neumayr, 1875

Subfamily Stephanoceratinae Neumayr, 1875

\subsection{Genus Pseudoteloceras nov.}

Type-species. Pseudoteloceras croisillense gen. et sp. nov. (Fig. 3).

Other species. Two nominal species are assigned to the new genus: Pseudoteloceras maerteni gen. et sp. nov. and Pseudoteloceras boursicoti gen. et sp. nov., both from the lower Bajocian, lower Humphriesianum Zone, Romani Subzone. A further taxon is represented by Teloceras geometricum Maubeuge, 1951 (p. 76, pl. 4, fig. 4) from an undefined layer of the Humphriesianum Zone at Halanzy, on the Franco-Belgian boundary, the morphology of which modifies from subcadiconic to planorbiconic with depressed trapezoidal whorl section; for Maubeuge's taxon we propose the new combination Pseudoteloceras geometricum (Maubeuge). Its holotype, the only known type-specimen, was doubtfully referred to the "zone à T. blagdeni?" by Maubeuge (1951, p. 76); it is a reelaborated internal mould that, if the original biostratigraphical reference is correct, was derived from the underlying fossil assemblage that mixes ammonites indicative of layers from the topmost Propinquans to the middle Humphriesianum zones. Therefore it can be interpreted as pre-Blagdeni Subzone and probably belonging to the Romani Subzone.

Etymology. Genus name Teloceras combined with the prefix "pseudo" with the meaning "resembling or imitating".

Diagnosis. Shells of small to medium size (micro- and macroconchs generally between 50 and $360 \mathrm{~mm}$ in diameter, respectively), evolute subcadicones, cadicones in the inner whorls, 
becoming planorbicones in the outer whorls, with depressed trapezoidal to subelliptical whorl section in the phragmocone and whorl-width proportionally reduced towards the adult bodychamber; coarse, strong, spaced and slightly sinuous primary ribs; prominent tubercles in the trifurcation points on the ventrolateral shoulder and straight or convex to forward projected secondaries. Microconchs with rounded-depressed whorl section egressed on the body-chamber; pointed to obsolete tubercles on the ventrolateral shoulder.

Description. Macroconchs are subcadicones of medium size with depressed, subtrapezoidal to elliptical section. The umbilicus is open, but relatively deep with steep flanks up to the acute ventrolateral shoulder in the inner whorls. The venter is slightly arched to flatten. Primary ribs are distant, sinuous, enlarged in the distal part and sometimes sharp. Trifurcation points lie in the outer flank at the ventrolateral shoulder and correspond to high tubercles, stout on the phragmocone and spiniform on the shells (or composite moulds). Secondary ribs cross the venter without interruption and describe a feeble to pronounced forward bend. Microconchs are small (50-60 mm) with rounded whorl-section, angular at the furcation point, just outside the mid-flank, with pointed to smoothed tubercles. Single ribs occur between bifurcate pairs. Peristome bears medium-long and narrow lappets. Suture line (Fig. 4) shows narrow and deeply incised E/L, large, slightly oblique lateral lobe, $\mathrm{L} / \mathrm{U}$ saddle larger than $\mathrm{E} / \mathrm{L}$ and symmetrically bipartite by a wide $U_{2}, U_{3}$ retracted and deep as $U_{2}$.

Regarding the microconchs, the dimorphic pairing is established only for $P$. croisillense gen. et sp. nov. and is evidenced by the co-occurrence of macro- and micro-counterparts in the same beds of the Chaudon section (see Pavia, 1983). Any other microconch counterpart of Pseudoteloceras gen. nov. is so far unknown. Our view is that it would be very difficult to corroborate from literature. The dimorphic coupling of Pseudoteloceras gen. nov. should be recognised only by co-occurrence of forms in the same fossil assemblage.

Discussion. Teloceras s.s., to which many authors referred these forms of the Romani Subzone (e.g., Callomon and Chandler, 1990; Chandler and Whicher, 2015; Ohmert et al., 1995), shows cadicones with regularly increasing whorl-width through the ontogeny, umbilical egression in the last whorl, shorter adult bodychamber (brevidomic or mesodomic; i.e., body-chamber with length whorl less than 360 degrees), denser primary ribs and tubercles, except in T. banksi of the lowermost upper Bajocian, more complex suture lines with deeply incised primary and secondary elements. Moreover, it is observed that Teloceras s.s. is recorded as beginning from the topmost Umbilicum Subzone with T. acuticostatum.

Chandler et al. (2013, p. 296) suggested a possible phyletic connection between the "Teloceras" of the Romani Subzone (recte Pseudoteloceras croisillense gen. et sp. nov.) and the Kumatostephanus present in Dorset up to the Humphriesianum Zone. Apart from this biochronologic anomaly (Kumatostephanus is recorded from the Laeviuscula and the lower Propinquans zones everywhere in the West-Tethys areas), Kumatostephanus shows coronate inner whorls becoming serpenticonic in the adult stage. A further stephanoceratin of the mid-lower Bajocian is Stemmatoceras, from which Pseudoteloceras gen. nov. differs for distinctive features such as more depressed trapezoidal whorl section, prominent ventrolateral shoulder, more spaced primary ribs, and blunt to spiniform tubercles.

Species of Stemmatoceras show a wide dispersion throughout the West-Tethys areas: from the central-European sector where they are most frequently listed in the upper Propinquans Zone (Hebridica Subzone, equivalent to the German Pinguis Subzone) and in the basal Humphriesianum Zone (Gassmann and Ohmert, 1990; Ohmert, 1990, 1994; Ohmert et al., 1995), to the Submediterranean (central France: Fernandez-Lopez and
Mouterde, 1994, p. 122) and Mediterranean (Della Bruna and Martire, 1985; Sandoval, 1990; Galacz, 1991) provinces. The records from the East-Pacific Realm enlarge the possible range of the species, but most records are not clearly and confidently congeneric within Mascke's taxon, or pertain to different species (Hall and Westermann, 1980; Westermann, 1992).

The type-species Stemmatoceras frechi was carefully described by Ohmert et al. (1995, p. 81, pl. 5, figs. 1-4, pl. 6, figs. 1-2) who highlighted its morphological features in relation to both Stephanoceras and Teloceras. Its morphology can be summarized as follow: medium-sized to large subcadiconic shell with depressed trapezoidal inner whorls becoming elliptical during ontogenesis; moderately open and deep umbilicus with rounded walls; spaced, slightly projected and concave primary ribs (24 on the last whorl at $87 \mathrm{~mm}$ diameter of the holotype); stout tubercles at the trifurcation point with regular intercalary ribs; suture line characterized by well-incised accessory elements of the lateral saddles and a deeply retracted umbilical lobe (Ohmert et al., 1995, fig. 17: very different to that one produced by Schlegelmilch, 1985, p. 77!). Besides the type-species, Ohmert et al. (1995) described two species, S. rauricum Ohmert, 1995 and S. triplex (Weisert, 1932). Moreover, Mascke (1907, p. 30) listed many taxa from the same layer of $S$. frechi that need formal definition as nomina nuda such as "S. crassispina", "S. ellipticum" (see Pavia, 1983, fig. 28), and "S. robustum" (personal observation of the coauthor G. P. in the geo-palaeontological Museum of Göttingen). Ohmert et al. (1995) referred to Mascke's genus a further coeval species, Teloceras geometricum Maubeuge, whose teloceriform features are out of the morphological spectrum of Stemmatoceras and it is referred more appropriately to Pseudoteloceras gen. nov.

As to the microconch equivalent of Stemmatoceras, the best candidate is the genus Platystomites Westermann, 1954 (Ohmert et al., 1995). The holotype of the type-species ("Gerzenites (Platystomites) platystomus" Westermann, 1954, p. 220, pl. 17, fig. 6, by original designation) comes from the "Pinguis-Schichten" of Goslar (N Germany), i.e. it is referred to the Hebridica Subzone as the type of Stemmatoceras frechi. In details, Ohmert et al. (1995, p. 82) specified that the microconch counterpart of Stemmatoceras frechi is Platystomites postrugosus (Westermann, 1954).

It is just worth noting the strict analogies among the microconchs of Stemmatoceras and Pseudoteloceras gen. nov. This evidence supports the evolutionary lineage connecting the latter genus to the former one, possibly through the large, fragmentary and unnamed specimen of Stemmatoceras with a trapezoidal whorl-section and depressed venter figured by Ohmert (1988, p. 339, pl. 8, fig. 9; 1990, p. 123, pl. 1, fig. 2). Based on the Stemmatoceras group of the central-European lower Bajocian, Hebridica Subzone, the appearance of the Teloceras-like morphology is first documented by Pseudoteloceras geometricum (Maubeuge) largely documented within the lower Humphriesianum Zone, from the Mediterranean Province (Alpi Feltrine, northeastern Italy: Della Bruna and Martire, 1985 as "Kumatostephanus (Stemmatoceras) geometricum") to the NW European Province (Halanzy at the Franco-Belgian boundary, Maubeuge, 1951; Dorset, southern England: Parsons, 2006, unpublished manuscript, pls. 11-12, as "Teloceras blagdeniforme" from the Sherborne area).

The so-called Stemmatoceras dubium Schmidtill and Krumbeck, 1938, Stemmatoceras hoffmanni Schmidtill and Krumbeck, 1938, Ammonites subcoronatum Oppel, 1856 in 1856-1858, and Skirroceras? triptolemum Buckman, 1912, are biostratigraphically located in the upper part of the Humphriesianum Zone (topmost Umbilicum and Blagdeni subzones), and disconnected from the stephanoceratids of the basal Humphriesianum Zone as demonstrated by Pavia (1983) from the sections of the Digne area. Their morphology strongly recalls that of Stemmatoceras, and for this reason most authors have assigned them to Mascke's genus (e.g., 

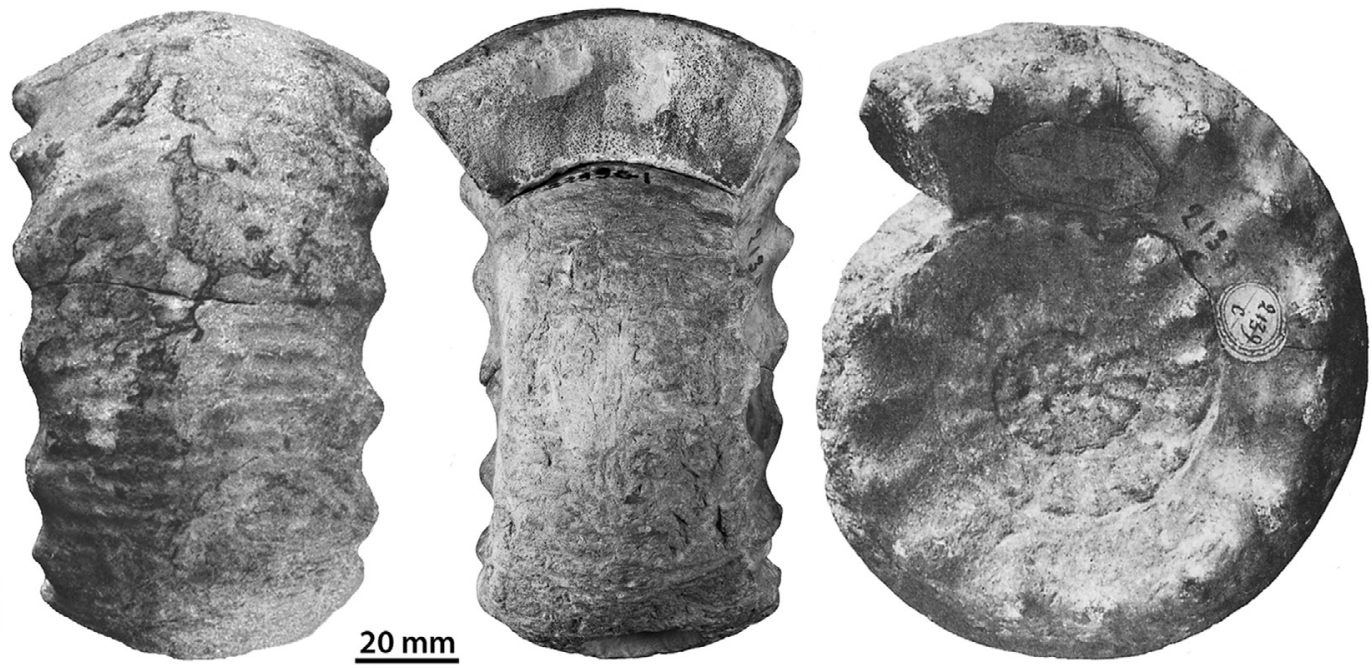

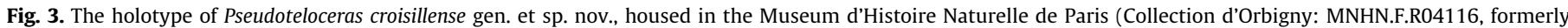
MHNP-2139c). Modified from Pavia, 1983, text-fig. 29. Asterisk marks the beginning of the body-chamber.

Fernandez-Lopez, 1985). However, Pavia (1983, p. 107) highlighted the absence of equivalent morphologies between the typical Stemmatoceras frechi of the transition from Propinquans to Humphriesianum zones and these Stemmatoceras-like forms of the topmost Umbilicum and Blagdeni subzones. For this set of species, intermediate between Stephanoceras and Teloceras, Gauthier et al. (1996) proposed the new nomenclatural combination Teloceras (Paviceras), whose type-species is Teloceras (Paviceras) hoffmanni (Schmidtill and Krumbeck, 1938). Further taxa of the upper Humphriesianum Zone, referable to Paviceras, are Teloceras (Paviceras) blagdeniforme (Roché, 1939) from the upper Humphriesianum Zone ("couches à Cad. Blagdeni du Mont d'Or Lyonnais” in Roché, 1939, p. 236; see also Gauthier et al., 1996, p. 35 from Feuguerolles-sur-Orne, and Pavia et al., 2015, from Croisilles), Stemmatoceras sp. nov. 2 from the Iberian Range (Fernandez-Lopez, 1985, p. 292), Stemmatoceras cf. frechi (Renz) form the Subbetic Domain (Sandoval, 1983, p. 252).

Occurrence. Pseudoteloceras gen. nov. is known from different bioprovinces of the early Bajocian West-Tethys. Its biochronostratigraphical range is so-far limited to the lower Humphriesianum Zone, Romani Subzone:

- NW European Province: Calvados (d'Orbigny, 1847 in 18421851; Gauthier et al., 1996; Pavia and Martire, 2010; Pavia et al.,

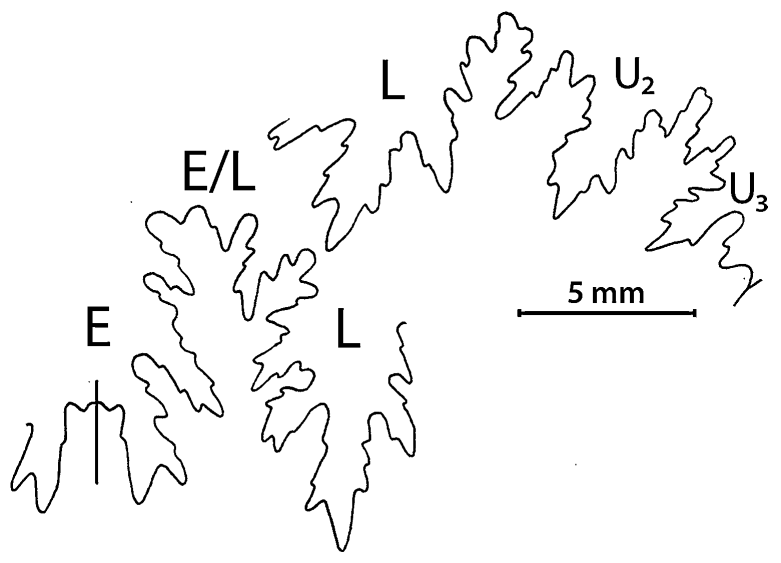

Fig. 4. Suture lines of Pseudoteloceras. croisillense gen. et sp. nov. A. Paratype MGPTPU112505 [m]. Chaudon section Bed 395.
2013, 2015), Dorset (Parsons, 1976; Callomon and Chandler, 1990; Chandler \& Whicher, 2015).

- Sub-Mediterranean Province: Central Massif of France (Mouterde, 1953; Fernandez-Lopez and Mouterde, 1994), Iberian Range (Fernandez-Lopez, 1985), Subalpine Basin (Pavia, 1983).

- Mediterranean Province: Southern Alps (Clari and Pavia, 1980; Della Bruna and Martire, 1985).

\subsection{Pseudoteloceras croisillense gen. et sp. nov.}

Figs. 3-6 7/A-H and 8/A-F-H and 8/A-F

Macroconchs [M]

v 1847 Ammonites Blagdeni, Sowerby - d'Orbigny, 1842-1851, p. 396, pl. 132.

1850 Ammonites Blagdeni, Sow. - Morris and Lycett, p. 110, pl. 14, fig. 3 .

? 1907 Stepheoceras Blagdeni - Haug, p. 1008.

1933 Teloceras sp. - Arkell, p. 221.

1976 Teloceras (T.) blagdeniformis (Roché) - Parsons, p. 131 (CP2965, figured by Parsons, 2006, pls. 3-4, unpublished manuscript).

1976 Teloceras (T.) blagdeniformis (Roché) - Parsons, p. 134 (CP2555, figured by Parsons, 2006, pl. 10, fig. 1 as Teloceras labrum, unpublished manuscript).

v 1983 Kumatostephanus (Stemmatoceras) sp. - Pavia, p. 108, pl.

17, figs. $1-3$.

v 1990 Teloceras labrum Buckman - Callomon and Chandler, p. 99 , pl. 4 , fig. 1.

v 1993 Teloceras? sp. - Pavia in Fischer, 1993, p. 120, pl. 43, fig. 1, pl. 44 , fig. 1.

? 1996 Kumatostephanus (Stemmatoceras) sp. - Gauthier et al., p. 33.

v 2010 "Stemmatoceras" blagdeni - Pavia and Martire, p. 77.

v 2013 "Teloceras Blagdeni (sensu d'Orbigny)" - Pavia et al., p. 141.

v 2015 ?Stemmatoceras nov. sp. 1 - Pavia et al., p.10, fig. 12.

v 2015 Teloceras cf. labrum (S. Buckman) - Chandler and Whicher, pl. 35, fig. 1.

non 2006 Teloceras blagdeniforme (Roché) - Parsons, pls. 11-12 (unpublished manuscript) $=$ Pseudoteloceras geometricum (Maubeuge).

Microconch [m] 
? 1954 Normannites (Gerzenites) crassicostatus, Westermann, p. 227, pl. 19, figs. 1-2, non pl. 18, fig. 6 = holotype of Platystomites crassicostatus (Westermann).

v 1983 Gerzenites (Platystomites) postrugosus (Westermann) Pavia, p. 139, pl. 26, figs. 1-3, 4-6.

Diagnosis. Macroconchs (adult diameter over $360 \mathrm{~mm}$ ): evolute subcadicones with trapezoidal whorl-section, feebly arched venter, spiniform to large tubercles at the trifurcation point and straight secondary ribs. Microconchs (diameter up to $60 \mathrm{~mm}$ ): subcadicones with rounded whorl-section and pointed to reduced tubercles at the bifurcation point with intercalary ribs.

Etymology. The species is named basing on the section of Croisilles, some four kilometres south of Les-Moutiers-en-Cinglais in Calvados (NW France).

Nomenclatural status. This species has been recorded with the name Teloceras (T.) blagdeniforme (Roché) by Mouterde (1953) from the Humphriesianum Zone of the French Central Massif and by Parsons (1976) from the Romani Subzone of Sherborne in Dorset, based on the references in the text of Roché (1939) to d'Orbigny's figure and description (see Parsons, 2006, unpublished manuscript). However, Pavia (1983, p. 109) stated that d'Orbigny's specimen cannot be regarded as the type of the species blagdeniforme because Roché (1939, p. 236) based its discussion on a particular ammonite "J'en figure un de très grande taille qui provient de la Ste Baume, dans mon étude sur les " couches à Cad. Blagdeni du Mont d'Or Lyonnais "”; this ammonite was described in detail and figured in a paper already listed "sous presse" in 1939 but printed four years later (Roché, 1943) because of the war. Such a delay does not prevent acceptance of Roché's original description made on a fossil in the hands of the author that is different from d'Orbigny's specimen, as discussed below. In conclusion, we confirm the proposition of Pavia (1983, p. 109) that the lectotype of Teloceras (Paviceras) blagdeniforme (Roché) is the specimen figured by Roché (1943, pl. 2, fig. 1), whereas d'Orbigny's specimen is free of any nomenclatural charge and may be used as holotype of the new taxon Pseudoteloceras croisillense gen. et sp. nov.

Holotype. Specimen MNHN.F.R04116 (formerly MHNP-2139c in d'Orbigny's Collection) housed in the Museum d'Histoire Naturelle de Paris, the single specimen cited by d'Orbigny (1847 in 18421851: cf. Pavia in Fischer, 1993) coming from the area of LesMoutiers-en-Cinglais (Fig. 3).

Locus typicus. D’Orbigny (1847 in 1842-1851, p. 396) did not give any indication useful to identify the type-locality of the holotype, except a general reference to the area of Les-Moutiers-en-Cinglais in Calvados. However, by lithofacies and preservational features, the fossil may be referred to bed 6 of the section described by Pavia et al. (2015) at "Les Fours à Chaux" $\left(49^{\circ} 00^{\prime} 28.59^{\prime \prime} \mathrm{N}\right.$ and $\left.0^{\circ} 26^{\prime} 02.91^{\prime \prime} \mathrm{E}\right)$ in the municipality of Croisilles, just south of Moutiers. The large preadult paratype collected from bed 6 of the Croisilles section (Fig. 5) adds further information in defining the formal statement of the species: it exactly fits with the holotype's morphological features and the lithofacies of their internal moulds are the same. The site of Les Fours à Chaux at Croisilles is thus here indicated as the most probable type-locality of Pseudoteloceras croisillense gen. et sp. nov.

Stratum typicum. The resedimented ammonites (Chondroceras evolvescens, C. gervillii and Poecilomorphus cycloides in Pavia et al., 2015) allow reference of Bed 6 of the section Les Fours à Chaux to the upper part of the Romani Subzone, Humphriesianum Zone, lower Bajocian.

Paratypes. Specimens MGPT-PU112498 [M] from Maizet and MGPT-PU112523 [M] from Croisilles. Twenty specimens from the section of Chaudon are considered as paratypes too: [M] MGPTPU112501-112504, MGPT-PU112506-112507, MGPT-PU112515, MGPT-PU112517-112519, MGPT-PU112525; [m] MGPTPU112505, MGPT-PU112508-112514, MGPT-PU112516.

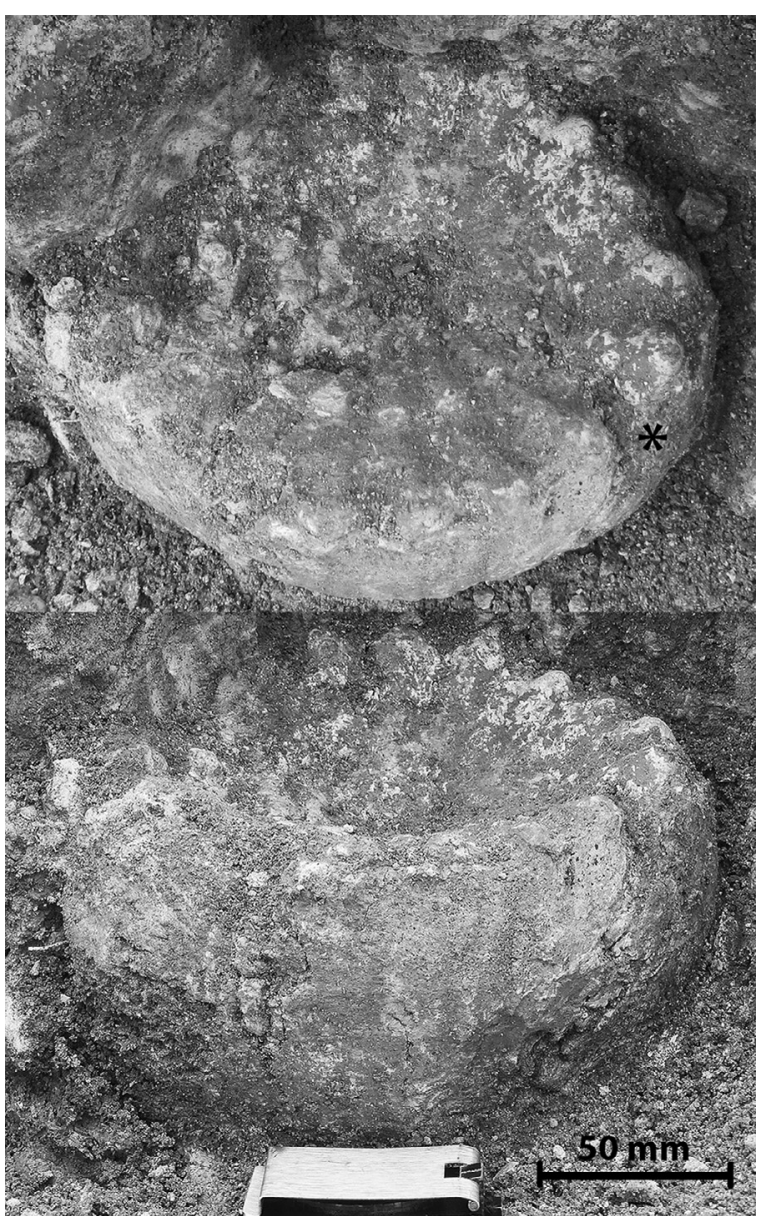

Fig. 5. A large, pre-adult specimen of Pseudoteloceras croisillense gen. et sp. nov. in the lower part of Bed 6 in the section of Les Fours à Chaux (cf. Pavia et al., 2015). Unfortunately, vertical faulting broke the fossil: it was possible to recover only the external whorl that is presently stored with code MGPT-PU112523. Asterisk marks the beginning of the body-chamber.

Material. Three specimens of the lower Humphriesianum Zone, Romani Subzone from the "Oolithe ferrugineuse de Bayeux" Formation: the holotype MHNP-2139c and the paratypes MGPTPU112523 and MGPT-PU112498 respectively from Croisilles and Maizet. Further specimens come from an interval of the "Marnocalcaires à Cancellophycus" Formation of the Digne area aged to early Humphriesianum Chron, latest Romani Subchron (Pavia, 1983): 1 [M] and $1[\mathrm{~m}]$ at the section of Feston; 37 [M] and $41[\mathrm{~m}]$ at the section of Chaudon. The largest specimens in collection measure $265 \mathrm{~mm}$ diameter (MGPT-PU112506, Fig. 6) and $290 \mathrm{~mm}$ in diameter (MGPT-PU112519) both from bed 395 of the Chaudon section (Pavia, 1983). We also took account of the fossil CP2965 from Dorset cited by Parson (1976, p. 131) and figured on Plates $3-$ 4 of his unpublished manuscript (Parsons, 2006) that provides information useful for a more complete and documented description of the new species.

Measurements. See Table 1.

Description. The material from the Subalpine Basin comprises macro- and microconchs that allow description of both dimorphs of the new species.

Adult peristomes of macroconchs are unknown but growth lines of largest shells are concave (cf. Callomon and Chandler, 1990); the length of the body-chamber exceeds one whorl. The coiling is evolute with umbilicus a bit more than $50 \%$. Shells are subcadiconic with subtrapezoidal whorl section $(\mathrm{W} / \mathrm{H}=2.3$ to 1.9 on the holotype), depressed venter gently arched in the middle and plan at the ventrolateral shoulder, flanks regularly sloped to 


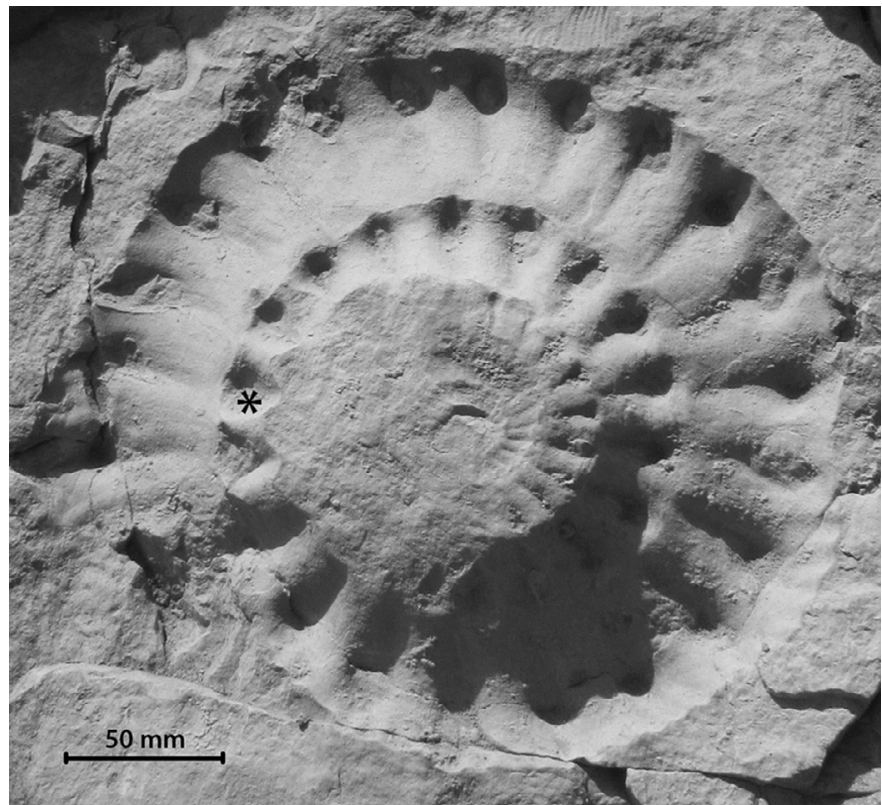

Fig. 6. A large external mould of Pseudoteloceras croisillense gen. et sp. nov. from Bed 395 of the section of Chaudon, Digne area. The equivalent internal mould is stored with code MGPT-PU112506 [M]. Asterisk marks the beginning of the bodychamber.

the spiral centre without any umbilical wall; there is no evidence of uncoiling of the whorl (egression) in any studied specimens (Fig. 6) even at $290 \mathrm{~mm}$ diameter. Ornament consists of coarse, acute and sinuous primary ribs, trifurcate with additional intercalary ribs. Secondary ribs are blunt, feebly convex to straight on the venter (Fig. 7/A and 7/D); they fade on the adult bodychamber. Tubercles of macroconchs are spiniform in the inner to medium whorls, whereas they enlarge and modify the lateral outline of the shell on the outer whorls (Figs. 3 and $7 / \mathrm{C}$ ).

On microconchs, the body-chamber is $210-220^{\circ}$ and bears long, not distally enlarged lateral lappets (Fig. 8/E). Whorl section is subcircular with regularly arched venter and maximum width on the mid-flanks; the body-chamber becomes more and more egressed. Ribbing is sharp with sinuous primaries and gently projected secondaries; the latter become prominent on the outer body-chamber. Tubercles are pointed, but may be reduced to a bulge on the bifurcation point. The septal suture is visible on pyritized internal mould of microconchs from Chaudon (Figs. 4 and 8/B). It shows narrow and deeply incised E/L saddle, large and slightly oblique lateral lobe lying on the ventrolateral shoulder and on the umbilical seam in the inner whorls, $\mathrm{L} / \mathrm{U}$ saddle larger than $\mathrm{E} / \mathrm{L}$ and symmetrically bipartite by a wide $\mathrm{U}_{2}, \mathrm{U}_{3}$ clearly retracted and deep as $U_{2}$; near the umbilical seam a short $U_{n}$ is clearly visible.

Discussion. Pseudoteloceras croisillense gen. et sp. nov. shows a certain degree of ornament variability on macroconchs: the specimens from Chaudon show a higher density of primary ribs, whereas in Dorset specimens the secondary ribs are less accentuated becoming obsolete on the venter (Callomon and Chandler, 1990; Chandler \& Whicher, 2015). Consistent in all specimens is the absence of umbilical walls, the proportional reduction of the whorl-width in the outer whorls that does not increase in the last ontogenetic growth phase, and the furcation rate $(\mathrm{Ne} / \mathrm{Ni})$ with average value 3.4.

Regarding the microconchs, the dimorphic status of $P$. croisillense gen. et sp. nov. is indicated by the co-occurrence of the macro- and micro-counterparts in the same beds of the Chaudon section (see Pavia, 1983, table IIIb; confirmation by 2015 studies on the same section). Pavia (1983, p. 139) identified these microconchs as Gerzenites (Platystomites) postrugosus (Westermann, 1954), but Ohmert et al. (1995, p. 82) assumed that Westermann's taxon fits more appropriately Stemmatoceras frechi (Renz, 1904) on the basis of well-preserved specimens coming from the Hebridica Subzone of Lörrach, SW Germany.

Regarding the references in the synonymy list, the holotype of Teloceras labrum Buckman, 1922 (in 1909-1930) comes from the so-called Epalxites hemera that refers to the upper part of the Humphriesianum Zone according to Buckman's Type Ammonites (1925 in 1909-30, V, p. 74). It shows a more arched ventral side and the suture line is typical of the genus Teloceras: L narrow, $2^{\text {nd }}$ lateral saddle asymmetrically divided, little retraction of the umbilical lobe. Thus, the specimen cited by Callomon and Chandler (1990, p. 99; see also Chandler \& Whicher, 2015) as Teloceras labrum cannot be attributed to Buckman's taxon on both morphological and stratigraphical grounds; it fits Pseudoteloceras croisillense gen. et sp. nov. The lectotype of Teloceras (Paviceras) blagdeniforme (Roché, 1939: see above) comes from the "couches à Cad. Blagdeni du Mont d’Or Lyonnais" (Roché, 1939, p. 206), i.e. the uppermost Humphriesianum Zone; its whorl-section is subrectangular on the phragmocone and becomes elliptical in the last whorl; the venter is

Table 1

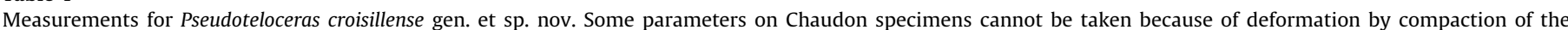

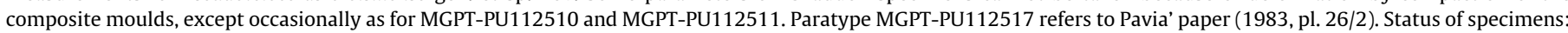

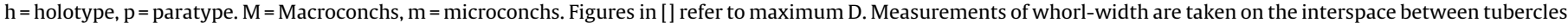
or (in brackets) on the tubercles.

\begin{tabular}{|c|c|c|c|c|c|c|c|c|c|c|c|c|c|}
\hline Specimens & Figures & & $\mathrm{D} \mathrm{mm}$ & $\mathrm{H} \mathrm{mm}$ & $\mathrm{h}$ & $\mathrm{W} \mathrm{mm}$ & $\mathrm{w}$ & $\mathrm{U} \mathrm{mm}$ & $\mathrm{u}$ & $\mathrm{W} / \mathrm{H}$ & $\mathrm{Ni} / 2$ & $\mathrm{Ne} / 2$ & $\mathrm{Ne} / \mathrm{Ni}$ \\
\hline \multirow[t]{2}{*}{ h - MNHN.F.R04116 } & Fig. 3 & {$[\mathrm{M}]$} & 134.0 & 36.0 & .27 & $67.0(74.0)$ & $.55(.50)$ & 67.0 & .50 & $1.9(2.1)$ & 8 & 28 & 3.5 \\
\hline & & & 106.0 & 27.0 & .25 & $61.0(65.0)$ & $.61(.56)$ & 52.0 & .50 & $2.3(2.4)$ & 7 & 24 & 3.4 \\
\hline \multirow[t]{2}{*}{ - СР2965 } & - & {$[\mathrm{M}]$} & 140.0 & 44.0 & .31 & $-(81.0)$ & $-(.58)$ & 72.0 & .52 & $-(1.8)$ & 8 & 26 & 3.3 \\
\hline & & & 121.0 & 42.0 & .34 & $-(70.0)$ & $-(.58)$ & 65.0 & .54 & $-(1.7)$ & 7 & 42 & 3.2 \\
\hline p - PU112501 & Fig. 6G & {$[\mathrm{M}]$} & 116.6 [126] & 33.6 & .30 & - & - & ca .63 & ca .54 & - & 10 & 36 & 3.6 \\
\hline p - PU112502 & Fig. $6 \mathrm{H}$ & {$[\mathrm{M}]$} & 85.0 & 25.4 & .30 & - & - & 38.3 & .48 & - & 10 & 35 & 3.5 \\
\hline p - PU112506 & Fig. 5 & {$[\mathrm{M}]$} & ca 150 [165] & ca 42 & ca .28 & - & - & ca 81 & ca .54 & - & 11 & 37 & 3.4 \\
\hline $\mathrm{p}$ - PU112507 & Fig. 6F & {$[\mathrm{M}]$} & ca 50 & ca 17 & ca .34 & - & - & ca 25 & ca .50 & - & 10 & 35 & 3.5 \\
\hline $\mathrm{p}-\mathrm{PU} 112525$ & Fig. 6E & {$[\mathrm{M}]$} & 39.7 & 12.8 & .32 & - & & 18.1 & .46 & - & 10 & 32 & 3.2 \\
\hline P - PU112505 & Fig. 3 & {$[\mathrm{~m}]$} & $30.5[45]$ & 9.4 & 32 & ca 14.0 & 47 & 13.2 & .43 & ca 1.3 & 11 & 27 & 2.5 \\
\hline p - PU112508 & Fig. 6D & {$[\mathrm{m}]$} & ca 46.5 [50] & ca 14 & ca .30 & - & - & ca 19 & ca .40 & - & 11 & 23 & 2.1 \\
\hline $\mathrm{p}-\mathrm{PU} 112509$ & Fig. 7A & {$[\mathrm{m}]$} & ca $56[70]$ & ca 20 & ca 38 & - & - & ca 23.5 & ca .42 & - & 10 & 26 & 2.6 \\
\hline $\mathrm{p}-\mathrm{PU} 112510$ & Fig. 7C & {$[\mathrm{m}]$} & 44.3 & 14.7 & .33 & $19.8(21.0)$ & $.47(.45)$ & 17.4 & .39 & $1.3(.1 .4)$ & 11 & 27 & 2.5 \\
\hline $\mathrm{p}$ - PU112511 & Fig. 7B & {$[\mathrm{m}]$} & 27.5 [40.7] & 8.5 & .31 & 13.3 & .48 & 11.4 & .41 & 1.6 & 11 & 24 & 2.2 \\
\hline $\mathrm{p}-\mathrm{PU} 112513$ & Fig. 7E & {$[\mathrm{m}]$} & $48.1[51]$ & ca 15.8 & .33 & - & - & ca 20.3 & ca .42 & - & 11 & 23 & 2.1 \\
\hline $\mathrm{p}-\mathrm{PU} 112516$ & Fig. 7F & {$[\mathrm{m}]$} & ca 46.5 [48.4] & ca 14.3 & ca 31 & - & - & ca 19.5 & ca 42 & - & 11 & 23 & 2.1 \\
\hline $\mathrm{p}-\mathrm{PU} 112517$ & Pavia' 83 & [m] & ca 43 [51] & ca 13.6 & 32 & - & - & ca 18.1 & ca 42 & - & 13 & 26 & 2.0 \\
\hline
\end{tabular}




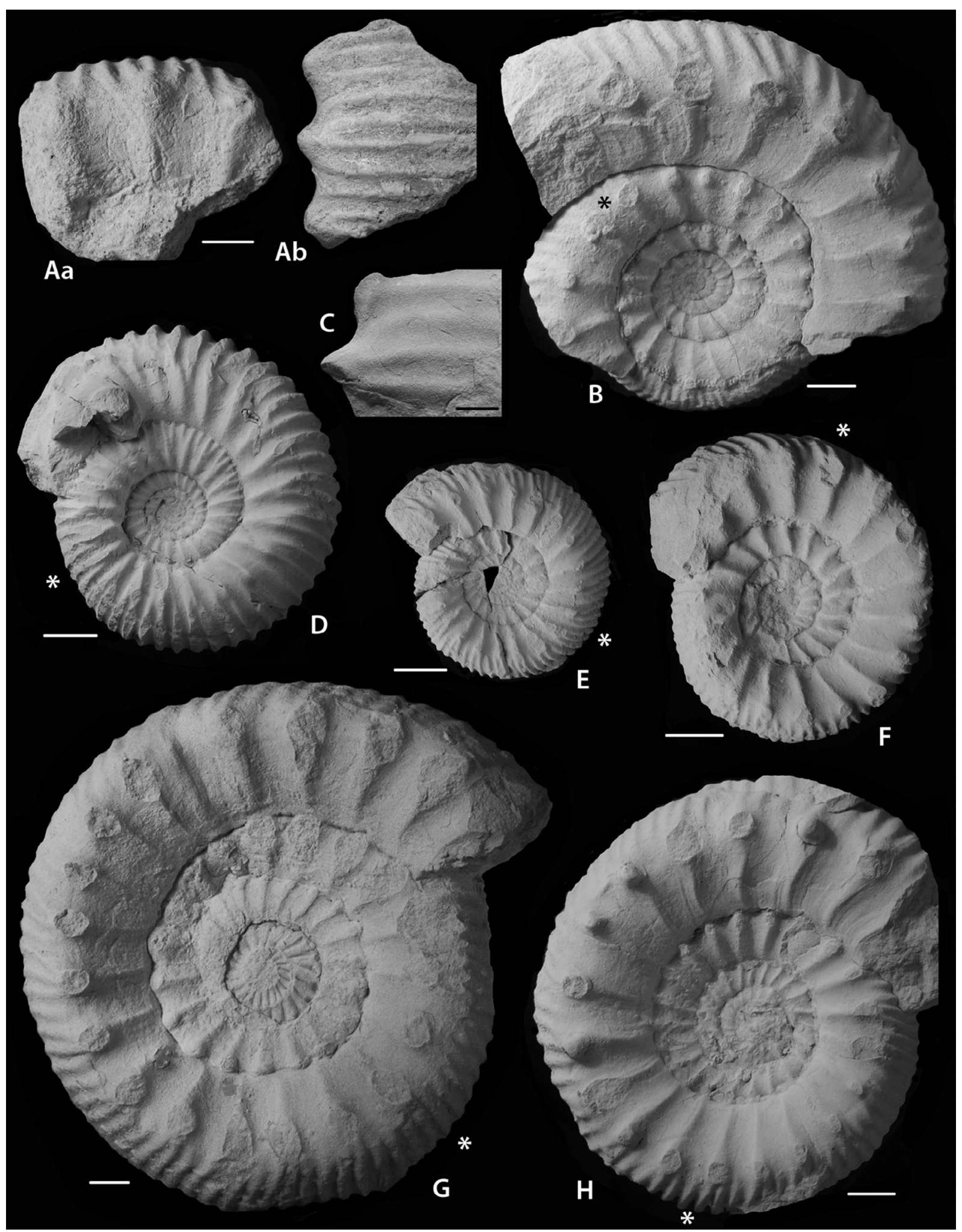

Fig. 7. A-G: Pseudoteloceras croisillense gen. et sp. nov. [M] et [m].

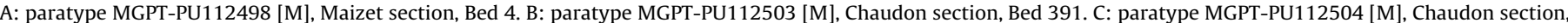

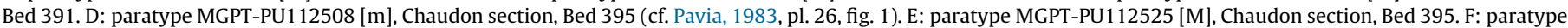

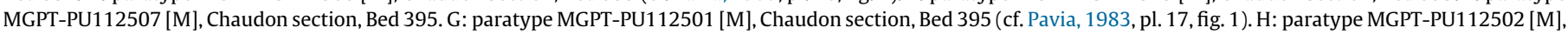
Chaudon section, Bed 395 (cf. Pavia, 1983, pl. 17, fig. 2).

Scale bars $=10 \mathrm{~mm}$. Asterisk marks the beginning of the body-chamber. 


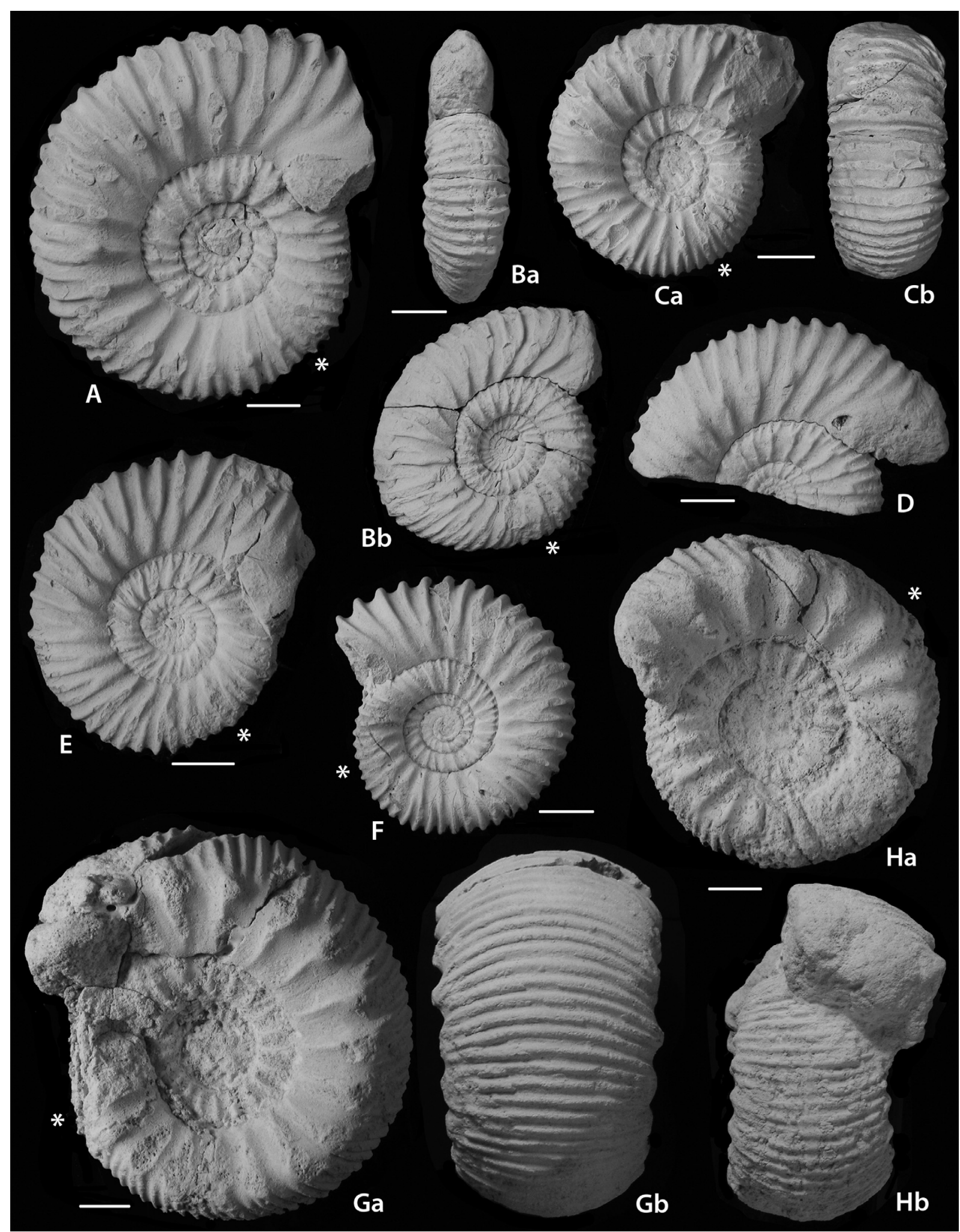

Fig. 8. A-F: Pseudoteloceras croisillense gen. et sp. nov. [m].

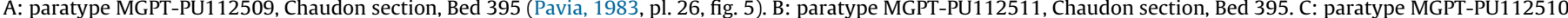

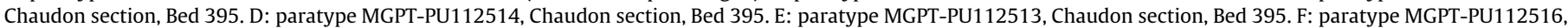

Chaudon section, Bed 395.

$\mathrm{G}-\mathrm{H}$ : Pseudoteloceras maerteni gen. et sp. nov. [M]

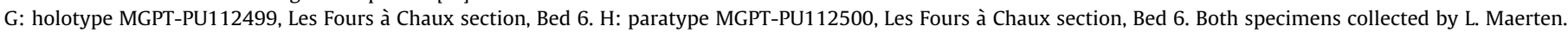
Scale bars $=10 \mathrm{~mm}$. Asterisk marks the beginning of the body-chamber. 
Table 2

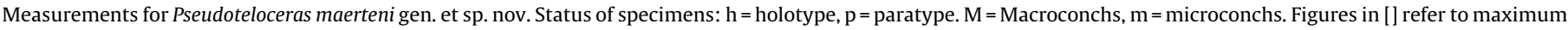
D. Measurements of whorl-width are taken on the interspace between tubercles or (in brackets) on the tubercles.

\begin{tabular}{|c|c|c|c|c|c|c|c|c|c|c|c|c|c|}
\hline Specimens & Figures & & $\mathrm{D} \mathrm{mm}$ & $\mathrm{H} \mathrm{mm}$ & $\mathrm{h}$ & $\mathrm{W} \mathrm{mm}$ & $\mathrm{w}$ & $\mathrm{U} \mathrm{mm}$ & $\mathrm{u}$ & $\mathrm{W} / \mathrm{H}$ & $\mathrm{Ni} / 2$ & $\mathrm{Ne} / 2$ & $\mathrm{Ne} / \mathrm{Ni}$ \\
\hline h - PU112499 & Fig. 7G & M & $69.5[74.4]$ & 23.5 & .34 & $40.9(44.1)$ & $.63(.59)$ & 27.2 & .39 & $1.7(1.9)$ & 10 & 41 & 4.1 \\
\hline p - PU112500 & Fig. $7 \mathrm{H}$ & M & 59.4 & 17.8 & .30 & $35.4(39.1)$ & $.66(.60)$ & 23.7 & .40 & $2.0(2.2)$ & 12 & 37 & 3.7 \\
\hline
\end{tabular}

arched; the umbilical egression of the external half of the bodychamber is marked; flanks show well definite umbilical walls; primary ribs are dense and straight with rectiradiate secondaries.

Distribution. Pseudoteloceras croisillense gen. et sp. nov. occurs in the upper Romani Subzone, lower Humphriesianum Zone. Its distribution is mainly documented in the North West European Province: Calvados (d'Orbigny, 1847 in 1842-1851; Haug, 1907; Pavia and Martire, 2010; Pavia et al., 2013) and Dorset (Morris and Lycett, 1850; Arkell, 1933; Parsons, 1976; Callomon and Chandler, 1990; Chandler and Whicher, 2015). However, the taxon is common also in the Subalpine Basin (Pavia, 1983) where a Pseudoteloceras croisillense Biohorizon may be defined at the upper part of the Romani Subzone (see Conclusions).

\subsection{Pseudoteloceras maerteni gen. et sp. nov.}

Figs. 8/G-H

Macroconch [M]

? 1953 Teloceras blagdeniforme Roché - Mouterde, p. 91.

v 1980 Stemmatoceras "blagdeni" - Clari and Pavia, p. 88.

? 1985 Stemmatoceras sp. nov. 1 - Fernandez-Lopez, p. 290, pl. 31, fig. 1.

? 1994 Teloceras? blagdeni (Sowerby) sensu d'Orbigny Fernandez-Lopez and Mouterde, p. 122.

1996 Teloceras (Teloceras?) labrum Buckman - Gauthier et al., p. 34, pl. 1, fig. 2 (non fig. 6).

2006 Teloceras blagdeniforme - Parsons, pl. 10, fig. 2 (unpublished manuscript)

v 2015 ?Stemmatoceras nov. sp. 2 - Pavia et al., p. 10.

Diagnosis. Moderately evolute subcadicones; depressed, subelliptical whorl-section with short umbilical walls, slightly rounded flanks and arched venter; strong primary ribs, convex secondaries and strong tubercles at the trifurcation point.

Etymology. The species is dedicated to Lionel Maerten (Ver-surMer, Calvados, France) who amicably collaborated in sampling the section Les-Fours-à-Chaux at Croisilles and collected both specimens that compose the type-series of this new taxon.

Holotype. Specimen MGPT-PU112499 housed in the paleontological collections of the Museo di Geologia e Paleontologia of the Torino University. The holotype comes from the base of Bed 6 of the section of Croisilles (Fig. 8/G).

Locus typicus. The type locality of the holotype is the site Les Fours à Chaux $\left(49^{\circ} 00^{\prime} 28.59^{\prime \prime} \mathrm{N}\right.$ and $\left.0^{\circ} 26^{\prime} 02.91^{\prime \prime} \mathrm{E}\right)$ in the municipality of Croisilles, South of Caen in Calvados (Pavia et al., 2015).

Stratum typicum. The resedimented ammonites (Chondroceras evolvescens, C. gervillii and Poecilomorphus cycloides in Pavia et al., 2015) allow referring Bed 6 of the section at Les Fours à Chaux to the upper part of the Romani Subzone, Humphriesianum Zone, Lower Bajocian.

Paratypes. Specimen MGPT-PU112500 [M] from Bed 6 of the section of Croisilles, the same place as the holotype.

Material. The holotype MGPT-PU112499 and the paratype MGPT-PU112500, from the Oolithe ferrugineuse de Bayeux Formation, are reelaborated fossils at the base of Bed 6 of the Croisilles section (see Pavia et al., 2015). The lithofacies of their internal moulds is a bioclastic packstone with fine and scattered Fe-ooids that is similar to that of the encasing bed 6 but totally different from those of the underlying Bed 5; thus the two fossils have to derive from a layer between beds 5 and 6 not recorded in the succession. Bed 5 has been referred to as the lower part of the Romani Subzone (Pavia et al., 2015), so that the holotype and the paratype of Pseudoteloceras maerteni gen. et sp. nov. have to be dated at the middle or late Romani Chron.

Measurements. See Table 2.

Description. Both holotype and paratype from Croisilles are immature macroconchs with a short tract of the body-chamber. Suture lines, though not easily detectable, do not show any approximation.

The coiling of macroconchs is moderately evolute with umbilicus at $39-40 \%$. Shells are subcadiconic; the subelliptical whorl section $(\mathrm{W} / \mathrm{H}=1.7-2.0)$ shows slightly rounded flanks with inclined umbilical walls, and arched venter. Ornament consists of coarse, sinuous primary trifurcate ribs with additional free secondaries regularly intercalated each triple bundle. Secondary ribs are blunt, gently projected forward. Tubercles lie on the ventrolateral shoulder, are pointed in the inner whorls on the umbilical seam and enlarge on the last whorls. The septal suture of these macroconchs cannot be drawn due to unfavourable preservation of the internal moulds. No microconch counterpart has been identified in the field or in the literature.

Discussion. The morphological features confirm that the definition of Pseudoteloceras maerteni gen. et sp. nov. as a new species is clear, though the sample is small. The diagnostic features of the species consist of a narrow umbilicus compared with conspecific taxa (39-40 vs 48-40), the degree of forward projection of the secondary ribs and the subelliptical whorl section with arched venter and short umbilical walls. On the other hand, the subcadiconic architecture with just slightly rounded flanks and the tubercles on the umbilical seam allow this species to be placed in Pseudoteloceras gen. nov., rather than in Stemmatoceras that is distinguished by its elliptical whorl-section with regularly rounded flank and venter and by blunt tubercles often reduced to a bulge at the furcation point. However, these morphological features assign $P$. maerteni gen. et sp. nov. to an intermediate position in the phyletic trend from Stemmatoceras to Pseudoteloceras gen. nov.

Distribution. Pseudoteloceras maerteni gen. et sp. nov. is present in different sites of the West-Tethys domain, from NW European Province (Gauthier et al., 1996; Parsons, 2006) to the Submediterranean (Mouterde, 1953; Fernandez-Lopez, 1985; FernandezLopez and Mouterde, 1994) and the Mediterranean provinces (Clari and Pavia, 1980). These references confirm our view that this species occurs in the lower Humphriesianum Zone.

\subsection{Pseudoteloceras boursicoti gen. et sp. nov.}

Figs. 8/A-Dv 2013 Teloceras labrum - Pavia et al., p. 141

v 2015 Teloceras cf. labrum (S. Buckman) - Chandler and Whicher, pl. 34, fig. 5.

Diagnosis. Evolute cadicones in the inner whorls; trapezoidal whorl-section with rounded umbilical walls, slightly rounded flanks and feebly arched venter; strong and sharp primary ribs, convex secondaries projected forward; spiniform, directed backwards tubercles at the trifurcation point. 
Etymology. The species is dedicated to Pierre-Ives Boursicot (Villedieu-la-Blouére, Maine-et-Loire, France) who collected the holotype in the temporary outcrop of Evrecy, South of Caen, whose succession is similar to that of Maizet (Pavia et al., 2013).
Holotype. Specimen MGPT-PU112524 housed in the paleontological collections of the Museo di Geologia e Paleontologia of the Torino University (Fig. 9/A). The holotype is a resedimented fossil coming from a packstone with randomly dispersed fine Fe-ooids of

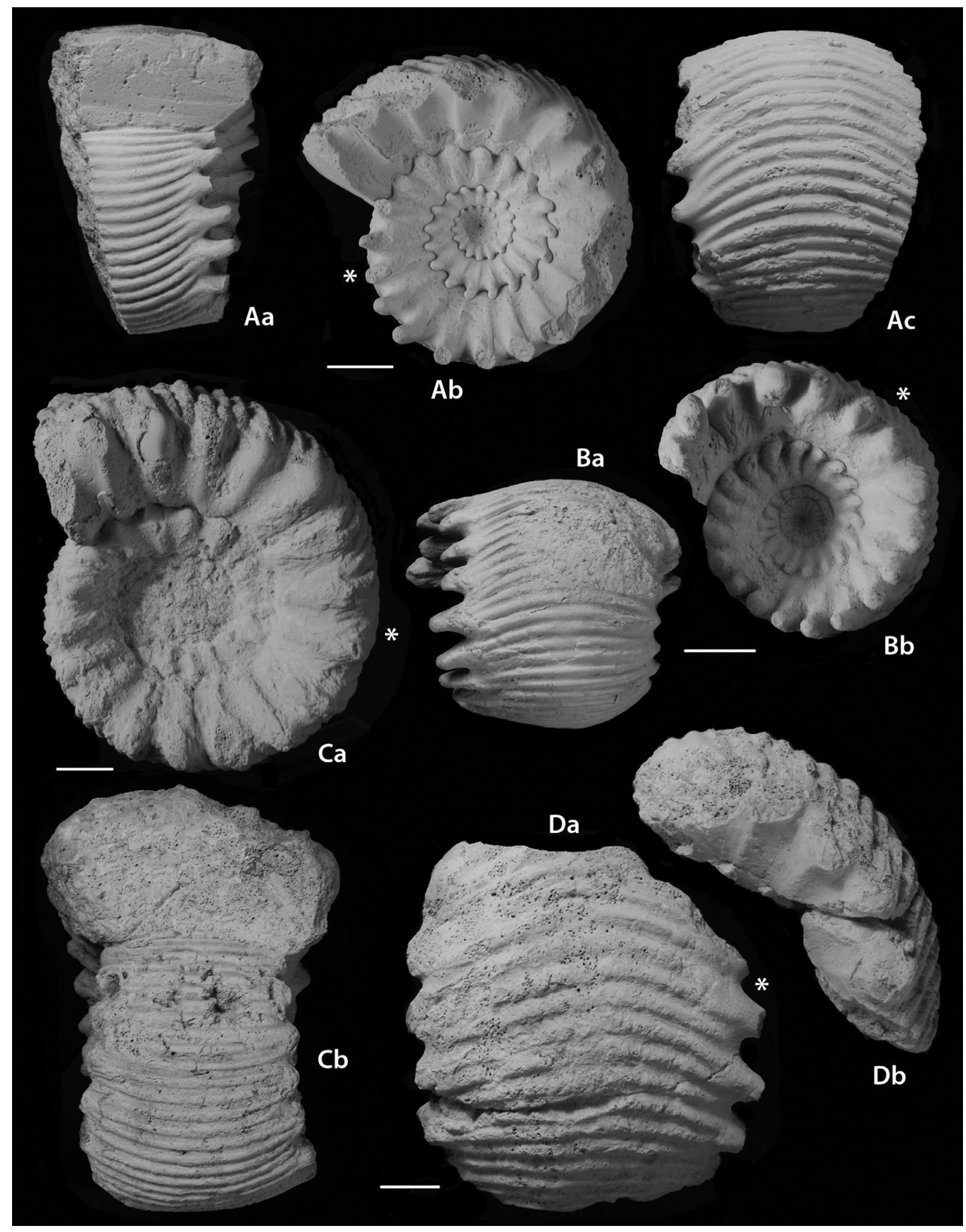

Fig. 9. A-D: Pseudoteloceras boursicoti gen. et sp. nov. [M].

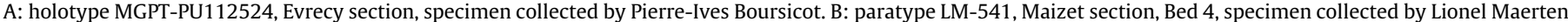

C: paratype MGPT-PU112520, Bretteville section, Bed 7. D: paratype MGPT-PU112521, Maizet section, Bed 4.

Scale bars $=10 \mathrm{~mm}$. Asterisk marks the beginning of the body-chamber 
Table 3

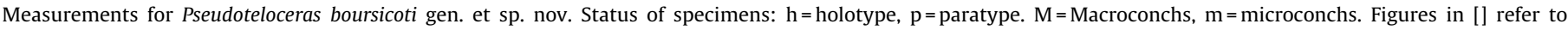
maximum D. Measurements of whorl-width are taken on the interspace between tubercles or (in brackets) on the tubercles.

\begin{tabular}{|c|c|c|c|c|c|c|c|c|c|c|c|c|c|}
\hline Specimens & Figures & & $\mathrm{D} \mathrm{mm}$ & $\mathrm{H} \mathrm{mm}$ & $\mathrm{h}$ & $\mathrm{W} \mathrm{mm}$ & w & $\mathrm{U} \mathrm{mm}$ & $\mathrm{u}$ & $\mathrm{W} / \mathrm{H}$ & $\mathrm{Ni} / 2$ & $\mathrm{Ne} / 2$ & $\mathrm{Ne} / \mathrm{Ni}$ \\
\hline h - PU112524 & Fig. 8A & {$[\mathrm{M}]$} & $46.6[52.1]$ & 14.3 & .31 & $34.4(39.8)$ & $.85(.66)$ & 25.5 & .55 & $2.4(2.8)$ & 9 & 25 & 2.8 \\
\hline \multirow[t]{2}{*}{$\mathrm{p}-\mathrm{PU} 112520$} & Fig. 8C & {$[\mathrm{M}]$} & 68.0 & 21.1 & .31 & $44.1(51.4)$ & $.76(.65)$ & 31.0 & .46 & $2.1(2.4)$ & 10 & 35 & 3.5 \\
\hline & & & 54.0 & 16.3 & .30 & $38.0(43.4)$ & $.80(.70)$ & 21.5 & .40 & $2.3(2.7)$ & 9 & 35 & 3.8 \\
\hline p - LM-541 & Fig. 8B & {$[\mathrm{M}]$} & 36.3 & 10.7 & .29 & $28.8(34.2)$ & $.94(.71)$ & 17.1 & .47 & $2.4(3.2)$ & 9 & 28 & 3.1 \\
\hline p - PU112521 & Fig. 8D & {$[\mathrm{M}]$} & - & 21.3 & - & $55.0(62.0)$ & - & - & - & $2.6(2.9)$ & - & - & 3.0 \\
\hline
\end{tabular}

the section of Evrecy, whose lithofacies is equivalent to that described in Bed 4 of the section of Maizet (Pavia et al., 2013, p. 141).

Locus typicus. The type locality of the holotype is the northern sector of the Evrecy municipality $\left(49^{\circ} 06^{\prime} 04.45^{\prime \prime} \mathrm{N}\right.$ and $\left.0^{\circ} 29^{\prime} 52.59^{\prime \prime} \mathrm{E}\right)$ where a temporary trench was opened in 2008 on a building site; thus at present no section is visible.

Stratum typicum. The resedimented ammonites associated to the holotype (Chondroceras evolvescens, C. gervillii and Poecilomorphus cycloides: Boursicot, pers. comm.) allow referring the source bed to the Lower Bajocian, Humphriesianum Zone, upper Romani Subzone by comparison with the Maizet section.

Paratypes. Specimen MGPT-PU112520 from Bretteville, specimens LM-541 and MGPT-PU112521 from Maizet.

Material. This new taxon is represented only by macroconchs; microconchs are hitherto unknown. The type-series totals five specimens of the lower Humphriesianum Zone, Romani Subzone from the Oolithe ferrugineuse de Bayeux" Formation: the holotype from Evrecy (MGPT-PU112524), a reelaborated fossil from Bed 7 at Bretteville (MGPT-PU112520), a resedimented specimen and a reelaborated one from Bed 4 at Maizet, respectively LM-541 (plaster mould MGPT-PU112522) and MGPT-PU112521, a resedimented specimen from Bed 6 at Croisilles (MGPT-PU112525). The resedimented specimens come from a bed in which the ammonite assemblage is characterized by Chondroceras evolvescens, C. gervillii and Poecilomorphus cycloides, and refers to the Romani Subzone. The two reelaborated specimens (MGPT-PU112520 and MGPT-PU112521) do not conflict with this biostratigraphical location because (1) the lithofacies of their internal moulds are equivalent to that of Bed 7 at Bretteville, Bed 4 at Maizet and Bed 6 at Croisilles, (2) MGPT-PU112520 from Bed 7 of Bretteville is regarded as a fossil reelaborated from the underlying Bed 6, and MGPT-PU112521 from Bed 4 at Maizet (erroneously stated to be from Bed 3 by Pavia et al., 2013, p. 141) is interpreted as derived from a directly underlying bed not recorded in the stratigraphical succession, but referred to the Romani Subzone.

Measurements. See Table 3.

Description. The coiling is evolute with umbilicus that varies from 46 to $55 \%$ during growth. Shells are cadiconic; the trapezoidal whorl-section $(\mathrm{W} / \mathrm{H}=2.1$ to 2.8$)$ shows slightly rounded flanks with short umbilical walls; the venter is flattened, just a little arched in the middle and pagodiform on the ventrolateral shoulders due to the long tubercles; no evidence of umbilical egression at the last preserved whorl. Ornament consists of spaced, slightly sinuous, trifurcate primary ribs with additional free secondaries intercalated each triple bundle; primaries are feeble on the umbilical wall and increase in relief towards the tubercles. Secondary ribs are blunt and bundle on tubercles; they regularly project forward. Tubercles lie on the ventrolateral shoulder, are pointed in the inner whorls on the umbilical seam and enlarge on the pre-adult stage; on specimens with the neomorphic shells, the tubercles develop spines turned backward (Fig. 9A and 9/B). The septal suture is hardly visible because of shell cover and bad preservation of internal moulds; nevertheless, it is composed of a narrow and deeply incised E/L saddle, large, slightly oblique lateral lobe located on the marginal part of the flattened venter, shallow $\mathrm{L} / \mathrm{U}$ saddle symmetrically bipartite by a wide $\mathrm{U}_{2}, \mathrm{U}_{3}$ deeply retracted.

Discussion. The convexity of the secondary ribs on the venter is particularly accentuated in the holotype of Pseudoteloceras boursicoti gen. et sp. nov. This feature marks a clear difference in comparison with the congeneric species. Another distinctive characteristic is represented by the spiniform tubercles directed backwards that produce a pagodiform outline of the venter. The variability of the species is further expressed by the ratio of whorl width to whorl height $(\mathrm{W} / \mathrm{H}$ 2.1-2.8 with the holotype in a middle position) and the furcation degree of the primary ribs (Ni/ Ne 2.8-3.7).

Distribution. The type-series of Pseudoteloceras boursicoti gen. et sp. nov. comes from the lower Bajocian, Humphriesianum Zone, Romani Subzone of the southern area of Caen, Calvados, NW France. The coeval record from Dorset (Chandler \& Whicher, 2015) certifies a larger distribution of the species within the northwestern European lower Humphriesianum Zone.

\section{Conclusions}

Pseudoteloceras gen. nov. represents a distinct phyletic lineage within the subfamily Stephanoceratinae. Its morphological features displayed in the inner whorls of the macroconchs are similar to those of the best known genus Teloceras. The differences from Teloceras are mainly morpho-structural and biochronological. Pseudoteloceras gen. nov. displays (1) subcadicones with planorbiconic outer whorls, regularly decreasing whorl-width towards the adult body-chamber without umbilical egression up to $300 \mathrm{~mm}$ diameter, (2) wider spaced primary ribbing, (3) convex secondary ribbing sometimes highly projected forward in the mid-venter, (4) simpler suture line. Moreover, Pseudoteloceras gen. nov. is older than Teloceras: the biochronologic range of Pseudoteloceras gen. nov. is limited to the early Humphriesianum Chron in the Western Tethys as supported by the literature and the new species, whereas the oldest Teloceras s.l. are recorded from the topmost Umbilicum Subzone.

The phyletic origin of Pseudoteloceras gen. nov. is likely to occur in the Stemmatoceras group of the Hebridica Subzone, upper Propinquans Zone, of the central-European lower Bajocian. In particular, we refer to the specimen Stemmatoceras sp. described by Ohmert (1988, p. 339, pl. 8, fig. 9; 1990, p. 123, pl. 1, fig. 2; original by Scholz, 1966) from the "Pinguis Subzone" of Glems bei Reutlingen, Germany, that shows an "unusual" subtrapezoidal whorl-section, depressed venter and pointed tubercles at the ventrolateral shoulder. The following step, with subcadiconic appearance and Teloceras-like morphology, is represented by Pseudoteloceras geometricum (Maubeuge). P. boursicoti gen. et sp. nov. may be regarded as the end term of a phyletic trend developed during the late Romani Subzone that finishes with the most accentuated Teloceras-like architecture in the inner whorls.

Pseudoteloceras geometricum is interpreted here as the earliest species of the new lineage. The three new species described in detail may be sequentially arranged in the upper Romani Subzone. The subcadicones with subelliptical whorl-section of Pseudoteloceras maerteni gen. et sp. nov., possibly located to the middle Romani 


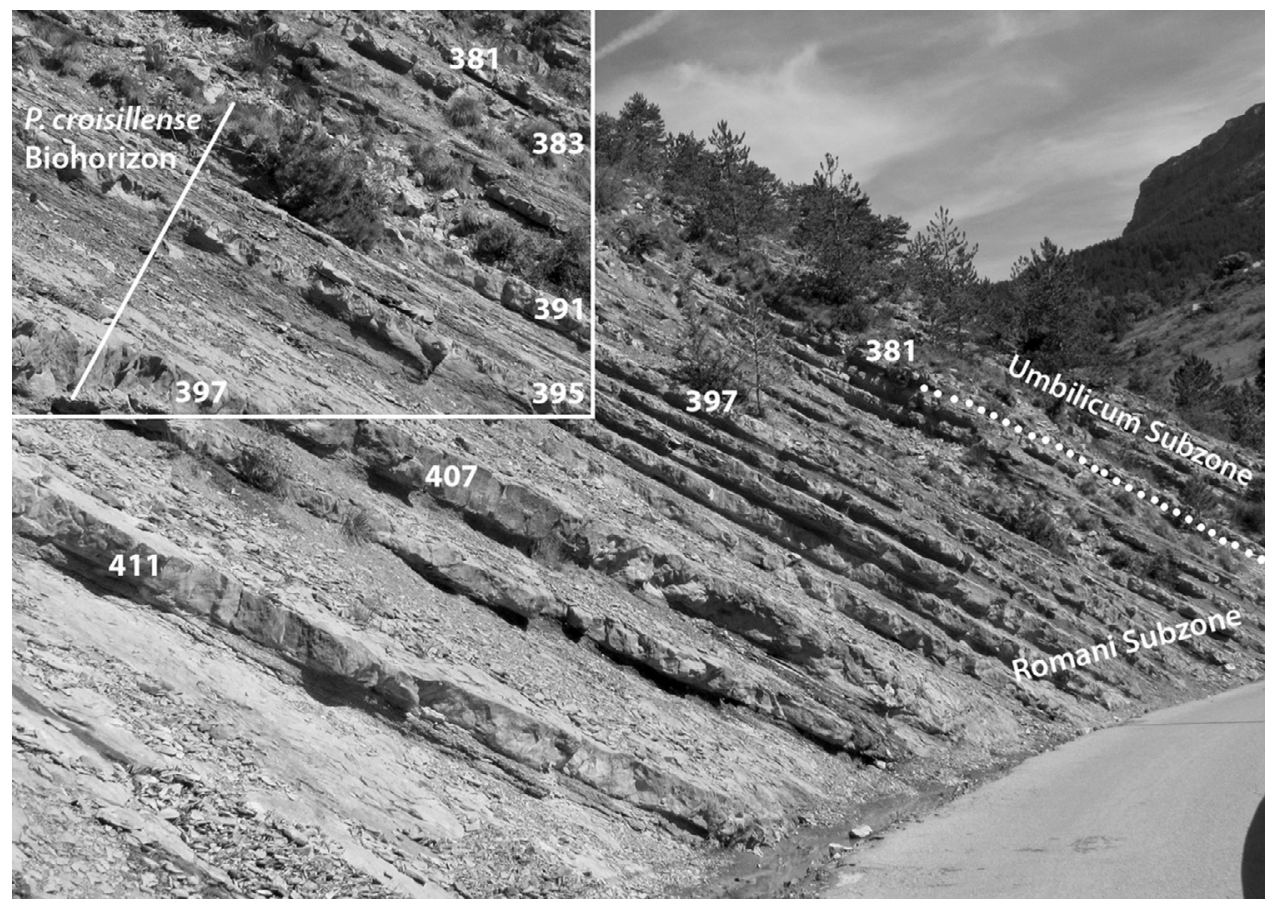

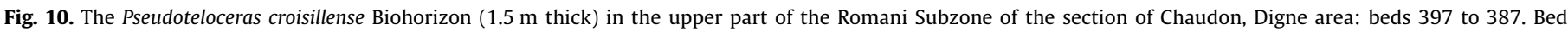

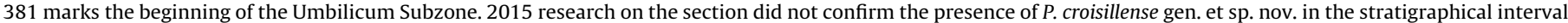
from beds 386 to 382, at the top of the Romani Subzone, as indicated by Pavia (1983, Tab IIIb).

Subzone, anticipated the definitive trapezoidal and cadiconic architecture of the inner whorls shown by Pseudoteloceras croisillense gen. et sp. nov. and Pseudoteloceras boursicoti gen. et sp. nov. In general, the latter three species refer to the upper Romani Subzone, the Gervillii Horizon (Fernandez-Lopez and Mouterde, 1994; Rioult et al., 1997, p. 49). The results from the section of Chaudon in the Subalpine Basin (Pavia, 1983, tab. IIIb) are more precise and reduce the distribution of $P$. croisillense gen. et sp. nov. to a relatively thin set of beds in the upper part of the Romani Subzone, so that it is possible to define a local Pseudoteloceras croisillense Biohorizon (Fig. 10) whose correlation potential needs to be confirmed in other areas of the western Tethys.

\section{Acknowledgements}

Many friends collaborated and facilitated the activity in the field: Pierre-Ives Boursicot (Villedieu-la-Blouére, France) for the fossils from Evrecy, Laurent Corbin (les-Moutiers-en-Cinglas, France) the owner of the old bureau of Les-Fours-à-Chaux at Croisilles, Aldo Defaveri (Alessandria, Italy) for help in excavation after many years in Calvados, Gérard Le Corsu (former Mayor of Maizet, France) for facilities in the field activity, Lionel Maerten (Ver-sur-Mer, France) for careful work in the field sampling and for putting at our disposal ammonites from Maizet and Croisilles, Myette Guyomar and Didier Bert of the Réserve Naturelle géologique de Haute Provence (Digne, France) for formal authorization to work in the reserve area. The bureau of the Museum National d'Histoire Naturelle de Paris (France) transmitted us information (Didier Merle) and photos (Peter Massicard) of the $P$. croisillense holotype. The clarity and impact of the final manuscript benefited from the action of the reviewers Robert Chandler plus an anonymous specialist and John Cope, the Coordinator of the PGA volume dedicated to late John Callomon. The study was supported by G. Pavia's personal grants and by S. Fernandez-Lopez research project CGL2011-23947 (MICINN) from the Spanish Ministry of Science and Innovation.

\section{References}

Arkell, W.J., 1933. The Jurassic System in Great Britain. Clarendon Press, Oxford, pp 681.

Arkell, W.J., Kummel, B., Wright, C.W., 1957. Mesozoic Ammonoidea. In: Moore, R.C (Ed.), Treatise on Invertebrate Paleontology. Part L., Mollusca 4. Geological Society of America and University of Kansas Press, Lawrence, pp. L80-L465.

Buckman, S.S., 1912. Ammonites from the Scarborough limestone. Proceedings of the Yorkshire Geological Society 17, 205-208.

Buckman, S.S., 1909-1930. Yorkshire Type Ammonites (1909-1913); Type Ammonites (1909-1930). Published by the author, London and Thame pls. 790.

Callomon, J.H., 1981. Superfamily Stephanocerataceae. Classification of the Jurassic Ammonitina. The Systematics Association 18, 120-123.

Callomon, J.H., 1985. The evolution of the Jurassic ammonite family Cardioceratidae. Special Papers in Paleontology 33, 49-90.

Callomon, J.H., 2003. The Middle Jurassic of western and northern Europe: its subdivisions, geochronology and correlations. Geological Survey of Denmark and Greenland Bulletin 1, 61-73.

Callomon, J.H., Chandler, R.B., 1990. A review of the ammonite horizons of the Aalenian-Lower Bajocian Stages in the Middle Jurassic of southern England. In: Cresta, S., Pavia, G. (Eds.), Proceedings of the Meeting on Bajocian Stratigraphy. Memorie descrittive della Carta geologica d'Italia, vol. 40. pp. 85-111.

Chandler, R.B., Whicher, J., 2015. Fossils of Dorset. Inferior Oolite ammonites from Lower Bajocian. Parker and Son, pp. 76

Chandler, R.B., Whicher, J., Grulke, W., Cowap, A., 2013. The Middle Jurassic stephanoceratid ammonite Kumatostephanus from Dorset and Somerset, UK, and its evolution. Geobios 46, 285-297.

Clari, P.A., Pavia, G., 1980. Osservazioni preliminari sulle facies condensate nel Giurassico delle Alpi Feltrine (Belluno). Paleontologia Stratigrafica ed Evoluzione $1,81-89$

Cuvier, G., 1795. Tableau élémentaire de l'histoire naturelle des animaux. Baudouin, Paris $710 \mathrm{pp}$

Della Bruna, G., Martire, L., 1985. La successione giurassica (Pliensbachiano Kimmeridgiano) delle Alpi Feltrine (Belluno). Rivista Italiana di Paleontologia e Stratigrafia 91, 15-62.

Dietl, G., Herold, G., 1986. Erstfund von Cadomites (Ammonoidea) im Unter-Callovium (Mittl, Jura) von Südwest-Deutschland. Stuttgarter Beitrage zur Naturkunde 120, 1-9.

Dietze, V., Wannenmacher, N., Franz, M., Schweigert, G., 2015. Lithological section and biostratigraphy of the Gosheim Formation in its type area (Lower Bajocian, Swabian Alb, SW Germany). Palaeodiversity 8, 31-69.

Fernandez-Lopez, S.R., 1985. El Bajociense en la Cordillera Ibérica. Thesis Doctoral. Departamento de Paleontología, Universidad Complutense de Madrid 850 pp.

Fernandez-Lopez, S.R., 1991. Taphonomic concepts for a theoretical biochronology Revista Española de Paleontología 6, 37-49.

Fernandez-Lopez, S.R., 1995. Taphonomie et interprétation des paléoenvironnements. In: Gayet, M., Courtinat, B. (Eds.). First European Palaeontological Congress, Lyon 1993. Geobios M.S. 18, 137-154. 
Fernandez-Lopez, S.R., 2007. Ammonoid taphonomy, palaeoenvironments and sequence stratigraphy at the Bajocian/Bathonian boundary on the Bas Auran area (Subalpine Basin, SE France). Lethaia 40, 377-391.

Fernandez-Lopez, S.R., 2011. Taphonomic analysis and sequence stratigraphy of the Albarracinites beds (lower Bajocian, Iberian Range, Spain). An example of shallow condensed section. Bulletin de la Société Géologique de France 182 405-415.

Fernandez-Lopez, S.R., 2014. Dimorphism and evolution of Albarracinites (Ammonoidea, lower Bajocian) from the Iberian Range (Spain). Journal of Systematic Palaeontology 12, 669-685.

Fernandez-Lopez, S.R., Mouterde, R., 1994. L'Horizon à Gervillii (Bajocien inférieur) de Tendron (Cher, France). Taphonomie et populations d'ammonites. In: Cresta, S. Pavia, G. (Eds.). Proceedings of the 3rd International Meeting on Aalenian and Bajocian Stratigraphy. Miscellanea del Servizio Geologico Nazionale 5, 117-159.

Fernandez-Lopez, S.R., Pavia, G., 2015. Mollistephaninae and Frebolditinae, new subfamilies of Middle Jurassic stephanoceratid Ammonoidea. Paläontologische Zeitschrift 89, 707-729.

Fischer, J.-C. (Ed.), 1993. Révision critique de la Paléontologie Française d'Alcide d'Orbigny. Volume I. Céphalopodes jurassique, Masson, Paris, p. 339.

Fischer, P.H., 1882. Manuel de Conchyliologie et de Paléontologie conchyliologique. Librairie F. Savy, Paris 1369 pp.

Galácz, A., 1991. Bajocian stephanoceratid ammonites from the Bakony Mountains, Hungary. Palaeontology 34, 859-885.

Galácz, A., 1994. Lokuticeras nov. gen.: a new genus for a Mediterranean Bajocian (Middle Jurassic) stephanoceratid ammonite group. In: Cresta, S., Pavia, G. (Eds.). Proceedings of the 3rd International Meeting on Aalenian, Bajocian Stratigraphy. Miscellanea del Servizio Geologico Nazionale 5, 161-173.

Gassmann, G., Ohmert, W., 1990. Der Humphriesi-Oolith von Egerten im Wollbachtal (Oberrheingebiet N Lörrach). Jahreshefte des geologischen Landesamts Baden-Württemberg 32, 159-170.

Gauthier, H., Rioult, M., Trévisan, M., 1996. Répartition biostratigraphique des ammonites dans l'Oolithe ferrugineuse de Bayeux (Bajocien) à Feuguerolles sur-Orne (Calvados). Eléments nouveaux pour une révision des Garantianinae. Géologie de la France 2, 27-67.

Graciansky, P.-C., Durozoy, G., Gigot, P., 1982.In: Carte géologique de la France à l'échelle 1:50000, Digne. Bureau de Recherches Géologiques et Minières, Paris pp. 75.

Grossouvre, A. de, 1930. Note sur le Bathonien moyen. Société Géologique de France, Livre jubilaire 2, 361-387.

Hall, R.L., Westermann, G.E.G., 1980. Lower Bajocian (Jurassic) cephalopod fauna from Western Canada and proposed assemblage zones for the lower Bajocian of North America. Palaeontographica Americana 9, 1-93.

Haug, E., 1907. Traité de Géologie. II. Les périodes géologiques. Armand Colin, Paris 467 pp.

Howarth, M.K., 2013. Part L, Revised, Volume 3B, Chapter 4: Psiloceratoidea, Eodoceratoidea, Hildoceratoidea. Treatise Online 57, 1-139.

Mascke, E., 1907. Die Stephanoceras-Verwandten in den Coronatenschichten von Norddeutschland. Inaugural-Dissertation, Universität Göttingen 38 pp.

Maubeuge, P.L., 1951. Les Ammonites du Bajocien de la région frontière francobelge (bord septentrional du Bassin de Paris). Mémoire de l'Institute Royale des Science Naturelles de la Belgique 42, 1-103.

Morris, J., Lycett, J., 1850. A monograph of the Mollusca from the Great Oolite chiefly from Minchinhampton and the coast of Yorkshire. Part I, univalves. Palaeontographical Society 4-8, 1-148.

Morton, N., 1971. Some Bajocian ammonites from western Scotland. Palaeontology $14,266-293$

Mouterde, R., 1953. Etudes sur le Lias et le Jurassique des bordures Nord et Nord-Est du Massif Central Français. Bulletin du Service de la Carte géologique de la France 50, 63-521.

Moyne, S., Neige, P., 2004. Cladistic analysis of the Middle Jurassic ammonite radiation. Geological Magazine 141, 115-123.

Munier-Chalmas, M., 1892. Etude préliminaire des terrains jurassiques de Normandie ( $2^{\text {me }}$ note). Compte-Rendu scientifiques de la Société géologique de la France 20, 156-170.

Neumayr, M., 1875. Die Ammoniten der Kreide und die Systematik der Ammonitiden. Zeitschrift der Deutschen Geologischen Gesellschaft 27, 854-892.

Ohmert, W., 1988. Das Unter-Bajocium von Badenweiler (Oberrhein), verglichen mit Nachbargebieten. Jahreshefte des geologischen Landesamts Baden-Württemberg 30, 315-347.

Ohmert, W., 1990. The Humphriesianum Zone in the type area. In: Cresta, S., Pavia, G. (Eds.). Proceedings of the 3rd International Meeting on Aalenian and Bajocian Stratigraphy. Memorie descrittive della Carta geologica d'Italia 40, 117-140.

Ohmert, W., 1994. The frechi horizon (humphriesianum Zone, Lower Bajocian) from the Oberrhein (South West Germany). Géobios, M.S. 17, 359-367.

Ohmert, W., Gassmann, G., Schatz, R.H., Stetter, L., 1995. Die höhere Unter-Bajocium (ehemals Mittel-Bajocium) von Lörrach. Jahreshefte des geologischen Landesamts Baden-Württemberg 35, 25-264.

Oppel, A., 1856-1858. Die Juraformation Englands, Frankreichs und des südwestlichen Deutschlands. Jahreshefte des Vereins für vaterländische Naturkunde in Württemberg 12-14, $857 \mathrm{pp}$.

Orbigny, A. d', 1842-1851. Paléontologie française, Terrains Jurassiques. Masson, Paris, pp. 642.

Page, K.N., 1993. Mollusca: Cephalopoda (Ammonoidea: Phylloceratina, Lytoceratina, Ammonitina, Ancyloceratina). In: Benton, M.J. (Ed.), The Fossil Record 2. Chapman and Hall, London, pp. 213-228.
Page, K.N., 1996. Mesozoic ammonoids in space and time. In: Landman, N.H., Tanabe, K., Davis, R.A. (Eds.), Ammonoid paleobiology. Topics in Geobiology, Volume 13. Plenum Press, New York, pp. 755-794.

Page, K.N., 2008. The evolution and geography of Jurassic ammonoids. Proceedings of the Geologist's Association 119, 35-57.

Parsons, C.F., 1976. A stratigraphic revision of the humphriesianum/subfurcatum Zone rocks (Bajocian Stage, Middle Jurassic) of Southern England. Newsletters on Stratigraphy 5, 114-142.

Parsons, C.F., 2006. The origins and evolution of the Bajocian, Middle Jurassic, ammonite genus Teloceras Mascke, 1907. Unpublished manuscript.

Pavia, G., 1983. Ammoniti e biostratigrafia del Baiociano inferiore di Digne (Francia SE, Dip. Alpes-Haute Provence) Museo Regionale di Scienze Naturali di Torino, Monografie II $254 \mathrm{pp}$

Pavia, G., Martire, L., 2010. Indirect biostratigraphy in condensed successions: a case history from the Bajocian of Normandy (NW France). Volumina Jurassica 7 , 67-76.

Pavia, G., Zunino, M., 2012. Ammonite assemblages and biostratigraphy at the lower to upper Bajocian boundary in the Digne area (SE France). Implications for the definition of the upper Bajocian GSSP. Revue de Paléobiologie spéc. 11, 205-227.

Pavia, G., Defaveri, A., Maerten, L., Pavia, M., Zunino, M., 2013. Ammonite taphonomy and stratigraphy of the Bajocian at Maizet, South of Caen (Calvados, NW France). Comptes Rendus de l'Académie des Sciences. Palevol 12, 137-148.

Pavia, G., Corbin, L., Defaveri, A., Maerten, L., Olivero, D., 2015. La formation de l'Oolithe ferrugineuse de Bayeux du Bajocien (Jurassique Moyen) au lieu dit "Les Fours à Chaux" entre Croisilles et Les-Moutiers-en-Cinglais (Calvados, NO France). Géologie de la France, 2015/2, 5-17.

Quenstedt, F.A., 1883-1888. Die Ammoniten des Schwäbischen Jura. Schweizerbart, Stuttgart $815 \mathrm{pp}$.

Renz, C., 1904. Der Jura von Daghestan. Neues Jahrbuch für Mineralogie. Geologie und Paläontologie 2, 71-85.

Rioult, M., Dugué, O., Du Chéne, J., Ponsot, C., Fily, G., Moron, J.M., Vail, P.R., 1991. Outcrop sequence stratigraphy of the Anglo-Paris Basin. Middle to Upper Jurassic (Normandie, Maine, Dorset). Bulletin du Centre des Recherches Exploration-Production Elf-Aquitaine. Mémoire 15, 101-194.

Rioult, M., Contini, D., Elmi, S., Gabilly, J., 1997. Bajocien. In: Cariou, E., Hantzpergue, P. (Eds.), Biostratigraphie du Jurassique ouest-européen et méditerranéen. Bulletin du Centre des Recherches Exploration-Production Elf-Aquitaine, Mémoire 17 , pp. $41-53$

Roché, P., 1939. In: Aalénien et Bajocien du MaçonnaisTravaux du Laboratoire de Géologie 29, Lyon, pp. 382.

Roché, P., 1943. Sur les couches dites à Ammonites Blagdeni du Mont d'Or Lyonnais. Travaux du Laboratoire de Géologie 30, Lyon, pp. 34.

Sandoval, J., 1983. Bioestratigrafía y Paleontología (Stephanocerataceae y Perisphinctaceae) del Bajocense y Bathonense en las Cordilleras Béticas. Thesis Doctoral, Departamento de Paleontología, Universidad de Granada 613 pp.

Sandoval, J., 1990. A revision of the Bajocian divisions in the Subbetic Domain (southern Spain). In: Cresta, S., Pavia, G. (Eds.). Proceedings of the Meeting on Bajocian Stratigraphy. Memorie descrittive della Carta geologica d'Italia 40, $141-162$.

Sandoval, J., O’Dogherty, L., Guex, J., 2001. Evolutionary rates of Jurassic ammonites in relation to sea-level fluctuations. Palaios 16, 311-335.

Sandoval, J., O'Dogherty, L., Vera, J.A., Guex, J., 2002. Sea-level changes and ammonite faunal turnover during the Lias/Dogger transition in the western Tethys. Bulletin de la Société Géologique de France 173, 57-66.

Schlegelmilch, R., 1985. Die Ammoniten des süddeutschen Doggers. Gustav Fischer Verlag, Stuttgart $284 \mathrm{pp}$

Schmidtill, E., Krumbeck, L., 1938. Die Coronaten-Schichten von Auerbach (Oberpfalz, Nordbayern). Zeitschrift der Deutschen Gesellschaft für Geowissenschaften 90, 297-360.

Scholz, H., 1966. Braunjuraprofil bei Glems (Kreis Reutlingen) am Fuß der Schwäbischen Alb. Bc Thesis. Universität Tübingen unpublished.

Waagen, W., 1869. Die Formenreihe des Ammonites subradiatus. Versuch einer paläontologischen Monographie. In: Benecke, E.W. (Ed.). Geognostiche-Paläontologische Beiträge 2, 179-256.

Westermann, G.E.G., 1954. Monographie der Otoitidae (Ammonoidea). Otoites, Trilobiticeras, Epalxites, Germanites, Masckeites (Pseudotoites, Polyplectites). Normannites. Beihefte zum Geologischen Jahrbuch 15, 1-364.

Westermann, G.E.G., 1956. Phylogenie der Stephanocerataceae und Perisphinctaceae des Dogger. Neues Jahrbuch für Geologie und Paläontologie. Abhandlungen 103, 233-279.

Westermann, G.E.G. (Ed.), 1992. The Jurassic of the Circum-Pacific. Cambridge University Press, 692 pp.

Westermann, G.E.G., 1996. Ammonoid life and habitat. In: Landman, N.H., Tanabe, K., Davis, R.A. (Eds.), Ammonoid paleobiology. Topics in Geobiology, Volume 13. Plenum Press, New York, pp. 607-707.

Westermann, G.E.G., 2005. Ammonites. In: Selley, R.C., Cocks, L.R.M., Plimer, I.R. (Eds.), Encyclopedia of Geology. Elsevier, London, pp. 396-407.

Weisert, K., 1932. Stephanoceras im Schwäbischen Braunen Jura delta. Palaeontographica A 76, 119-191

Wetzel, W., 1937. Studien zur Paläontologie des nordwestdeutschen Bathonien. Palaeontographica A 87, 77-157.

Zittel von, K.A., 1884. Handbuch der Paläontologie. 1. Abteilung. Band 2. Lieferung 3. Cephalopoda. R. Oldenburg. München and Leipzig 329-522. 